\title{
The W. A. Ford Site (41TT2), Titus County, Texas
}

Timothy K. Perttula

Heritage Research Center, Stephen F. Austin State University

Follow this and additional works at: https://scholarworks.sfasu.edu/ita

Part of the American Material Culture Commons, Archaeological Anthropology Commons, Environmental Studies Commons, Other American Studies Commons, Other Arts and Humanities Commons, Other History of Art, Architecture, and Archaeology Commons, and the United States History Commons

Tell us how this article helped you.

This Article is brought to you for free and open access by the Center for Regional Heritage Research at SFA ScholarWorks. It has been accepted for inclusion in Index of Texas Archaeology: Open Access Gray Literature from the Lone Star State by an authorized editor of SFA ScholarWorks. For more information, please contact cdsscholarworks@sfasu.edu. 


\section{The W. A. Ford Site (41TT2), Titus County, Texas \\ Creative Commons License \\ (c) $($ ) (8) 8}

This work is licensed under a Creative Commons Attribution-NonCommercial 4.0 International License 


\title{
The W. A. Ford Site (41TT2), Titus County, Texas
}

\author{
Timothy K. Perttula
}

\section{INTRODUCTION}

The W. A. Ford site (41TT2) is an ancestral Caddo cemetery on a natural sandy knoll on an alluvial terrace about $2 \mathrm{~km}$ south of the Sulphur River, along Sanders Slough, in the northwestern part of Titus County, Texas (Figures 1 and 2). There are also habitation deposits of both Woodland and Caddo age at the site, but no features were identified in these habitation deposits during the 1934 University of Texas investigations (Goldschmidt 1934, 1935a, 1935b). The site is located in the modern Blackland Prairie habitat, but just to the north of the northern extent of the modern Post Oak Savannah. In this article, I focus on the 11 burial features that were excavated in a small cemetery at the W. A. Ford site, which apparently are from at least two temporally sequent Caddo occupations, as well as the analysis of the 36 ceramic vessels placed as funerary offerings with nine of the 11 burials.

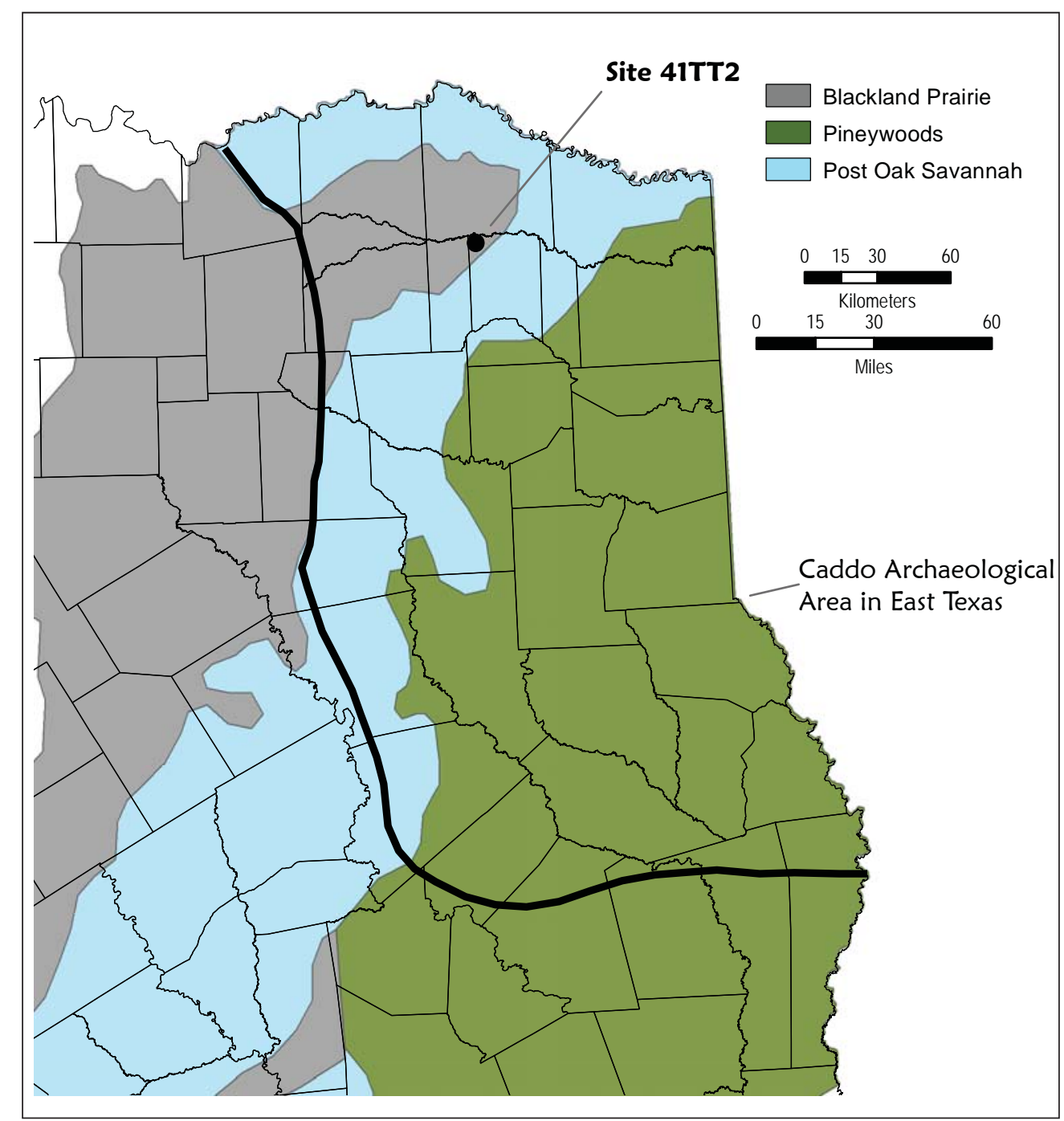

Figure 1. Location of the W. A. Ford site (41TT2) in East Texas. 




Figure 2. The location of the W. A. Ford site relative to the modern channel of the Sulphur River and Sanders Slough in Titus County, Texas.

\section{Site Excavations and Burial Contexts}

The W. A. Ford site was excavated by University of Texas (UT) archaeologists in August and September 1934 under the direction of the archaeological foreman Walter R. Goldschmidt (1934). The site was on land commonly known as the Sam Harper Place, but in 1934 it was owned by W. A. Ford. During the grading of a nearby highway (now U.S. 271) in 1932, a Mr. Pat Davis of Talco, Texas (only $2.5 \mathrm{~km}$ to the south of the site), had exposed human remains and three associated ceramic vessels. A. T. Jackson of UT had been shown the general locale of the finds, and he recommended that UT conduct excavations at the site. The UT excavations began on August 21 in an unproductive area, but the crew was shown the exact place where Pat Davis had uncovered the human remains and vessels (Goldschmidt 1934:2), and trenching began the same day. On the second day of the excavations, the first two of the 11 burials at the site were found by the UT crew.

The excavations consisted of a series of trenches east of the highway ditch, opening an area of approximately $70 \mathrm{ft}$. (ca. $21.3 \mathrm{~m}$ ) north-south and $70 \mathrm{ft}$. (ca. $21.3 \mathrm{~m}$ ) east-west, with a series of trenches extending northwest, north, northeast, and southeast from the main excavation block (Figure 3). During the excavations 11 ancestral Caddo burial features (Burial X-1 to $\mathrm{X}-11$ ) were uncovered in the main block (Table 1). Ten of the 11 burials had been placed in graves in an extended supine position; the position of Burial X-4 could not be determined in the field. With the exception of Burial X-6, which was oriented with the deceased's head facing to the east-northeast, the other nine burials generally faced west-southwest $(n=7)$ 
or west ( $\mathrm{n}=2)$. The burial pits ranged from $102-213 \mathrm{~cm}$ in length, $36-122 \mathrm{~cm}$ in width, and $46-102 \mathrm{~cm}$ bs in depth. These burials held adolescents as well as adults, and Burial X-8 had two individuals.

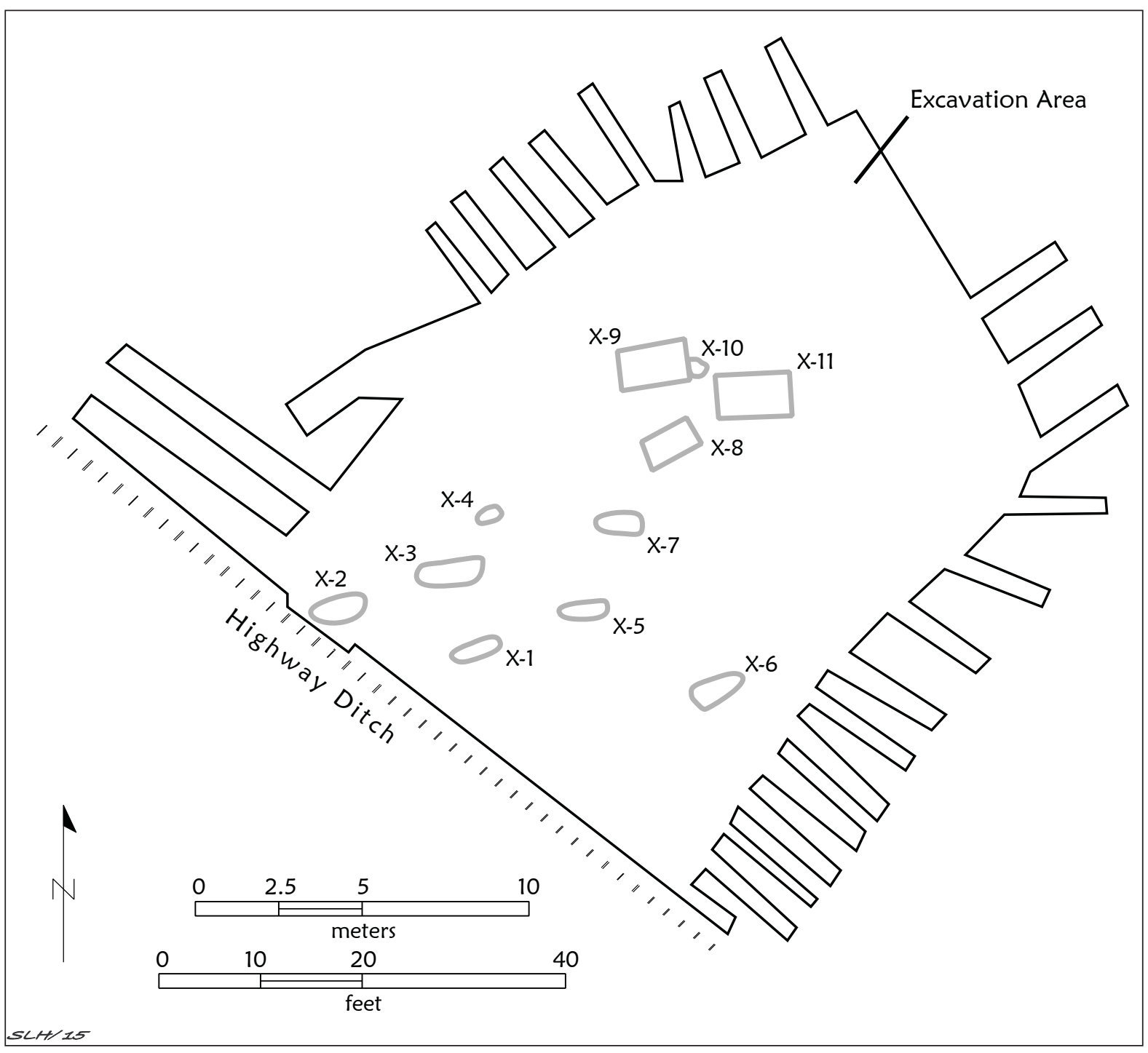

Figure 3. Map of the 1934 excavations at the W. A. Ford site and the location of Burials $X-1$ to $X-11$.

Table 1. Burial features at the W. A. Ford site.

\begin{tabular}{llllll}
\hline $\begin{array}{l}\text { Burial } \\
\text { No. }\end{array}$ & Orientation* & $\begin{array}{l}\text { Length } \\
(\mathrm{cm})\end{array}$ & $\begin{array}{l}\text { Width } \\
(\mathrm{cm})\end{array}$ & $\begin{array}{l}\text { Depth } \\
(\mathrm{cm})\end{array}$ & $\begin{array}{l}\text { Funerary } \\
\text { Offerings** }\end{array}$ \\
\hline $\mathrm{X}-1$ & $\begin{array}{l}\text { Extended, } \\
\text { W-SW }\end{array}$ & 158 & 36 & 56 & 1 Vessel, \\
$\mathrm{X}-2$ & $\begin{array}{l}\text { Extended, } \\
\text { W-SW }\end{array}$ & 173 & 61 & 76 & $\begin{array}{l}\text { 3 Vessels, } \\
1 \text { Stone tool }\end{array}$ \\
$\mathrm{X}-3$ & $\begin{array}{l}\text { Extended, } \\
\text { W-SW }\end{array}$ & 213 & 71 & 91 & 3 Vessels \\
$\mathrm{X}-4$ & Unidentified & N/A & N/A & 46 & 1 Vessel, \\
& & & & & \\
& & & & &
\end{tabular}


Table 1. Burial features at the W. A. Ford site, cont.

\begin{tabular}{|c|c|c|c|c|c|}
\hline $\begin{array}{l}\text { Burial } \\
\text { No. }\end{array}$ & Orientation* & $\begin{array}{l}\text { Length } \\
(\mathrm{cm})\end{array}$ & $\begin{array}{l}\text { Width } \\
\text { (cm) }\end{array}$ & $\begin{array}{l}\text { Depth } \\
\text { (cm) }\end{array}$ & $\begin{array}{l}\text { Funerary } \\
\text { Offerings** }\end{array}$ \\
\hline $\mathrm{X}-5$ & $\begin{array}{l}\text { Extended, } \\
\text { W-SW }\end{array}$ & 149 & N/A & 66 & None \\
\hline$X-6$ & $\begin{array}{l}\text { Extended, } \\
\text { E-NE }\end{array}$ & 132 & 74 & 81 & 2 Vessels \\
\hline$X-7$ & $\begin{array}{l}\text { Extended, } \\
\mathrm{W}\end{array}$ & 102 & 51 & 46 & 1 Vessel \\
\hline $\mathrm{X}-8$ & $\begin{array}{l}\text { Extended, } \\
\text { W-SW, Two } \\
\text { Individuals }\end{array}$ & 147 & 89 & 102 & $\begin{array}{l}8 \text { Vessels***, } \\
1 \text { Celt, } \\
12 \text { Arrow points }\end{array}$ \\
\hline$X-9$ & $\begin{array}{l}\text { Extended, } \\
\text { W-SW }\end{array}$ & 203 & 122 & 76 & $\begin{array}{l}10 \text { Vessels*** } \\
3 \text { Arrow points }\end{array}$ \\
\hline$X-10$ & $\begin{array}{l}\text { Extended, } \\
\text { W-SW }\end{array}$ & N/A & ca. 61 & 56 & None \\
\hline$X-11$ & $\begin{array}{l}\text { Extended, } \\
\text { W }\end{array}$ & 213 & 122 & 91 & $\begin{array}{l}10 \text { Vessels*** } \\
16 \text { Arrow points }\end{array}$ \\
\hline
\end{tabular}

*including the direction the head is facing

**from Goldschmidt (1934)

***There are seven vessels in the TARL collection from Burial X-8, nine vessels from Burial X-9, and nine vessels from Burial X-11

Nine of the 11 burials had associated funerary offerings, including ceramic vessels (in all nine burials), arrow points, celts, or other stone tools (in six of the burials). Other funerary offerings included a piece of quartz, mussel shells, a green (glauconite) clay pigment, and an unmodified beaver incisor tooth.

\section{Burial $X-1$}

Burial $\mathrm{X}-1$ was that of an adult in the western part of the cemetery that had been placed in an extended supine position with the head facing to the west-southwest (Figure 4). Associated with the burial was a single plain bowl (Vessel No. 1) by the upper left leg (Figure 4).

\section{Burial $X-2$}

This burial is also that of an adult (Figure 5) about $3 \mathrm{~m}$ northwest of Burial $\mathrm{X}-1$. The three ceramic vessels were placed either by the head (Vessel No. 3, a noded bowl) or by the upper left leg (Vessel No. 5, a plain carinated bowl). Goldschmidt (1934:6) also stated that Vessel No. 4 (a lip notched bowl) rested on the face of the deceased, but did not note the location of the one chert chipped stone tool on his burial plan.

\section{Burial $\mathrm{X}-3$}

Burial $\mathrm{X}-3$ is that of an adult; it is about $2 \mathrm{~m}$ north of Burial $\mathrm{X}-1$ (see Figure 3 ). The three ceramic vessels placed with the deceased as funerary offerings include a plain globular bowl (Vessel No. 7) by the upper left arm, an incised jar (Vessel No. 8) by the upper right leg, and an incised-punctated jar (Vessel No. 9) by the lower right leg (Figure 6). 


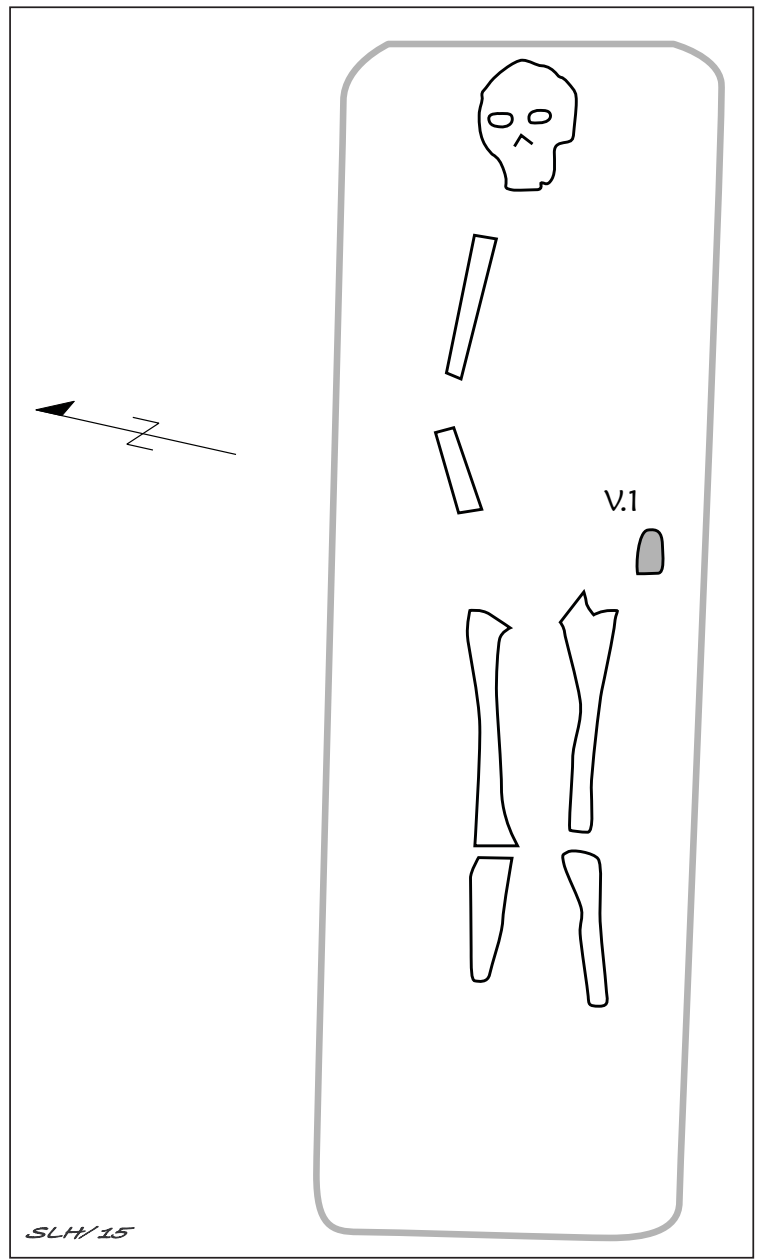

Figure 4. Burial $\mathrm{X}-1$ at the W. A. Ford site.

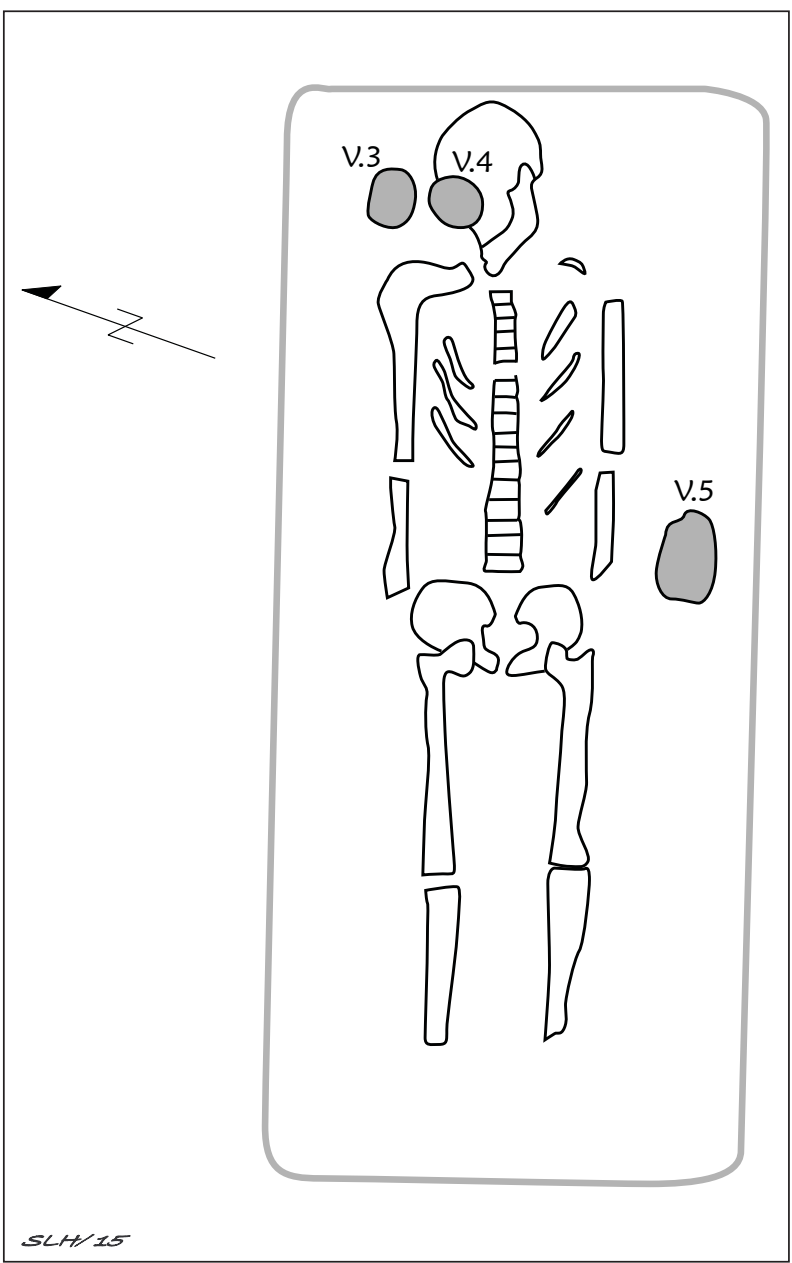

Figure 5. Burial X-2 at the W. A. Ford site.

\section{Burial $X-4$}

The orientation of Burial X-4 could not be determined, and consisted of a few skull fragments, teeth, and other unidentified human bone fragments about $1.5 \mathrm{~m}$ north of Burial X-3 (see Figure 3). Associated with the human remains was a single plain bowl (Vessel No. 10).

\section{Burial $X-5$}

Burial $\mathrm{X}-5$ was a poorly preserved extended burial, possibly of an adolescent based on the size of the burial pit (Figure 7, see also Table 1). This burial was about $3 \mathrm{~m}$ northeast of Burial X-1 (see Figure 3). There were no associated funerary offerings, but Goldschmidt (1934:11) did note the occurrence of sherds, burned clay, and two stone tools in the burial fill. 


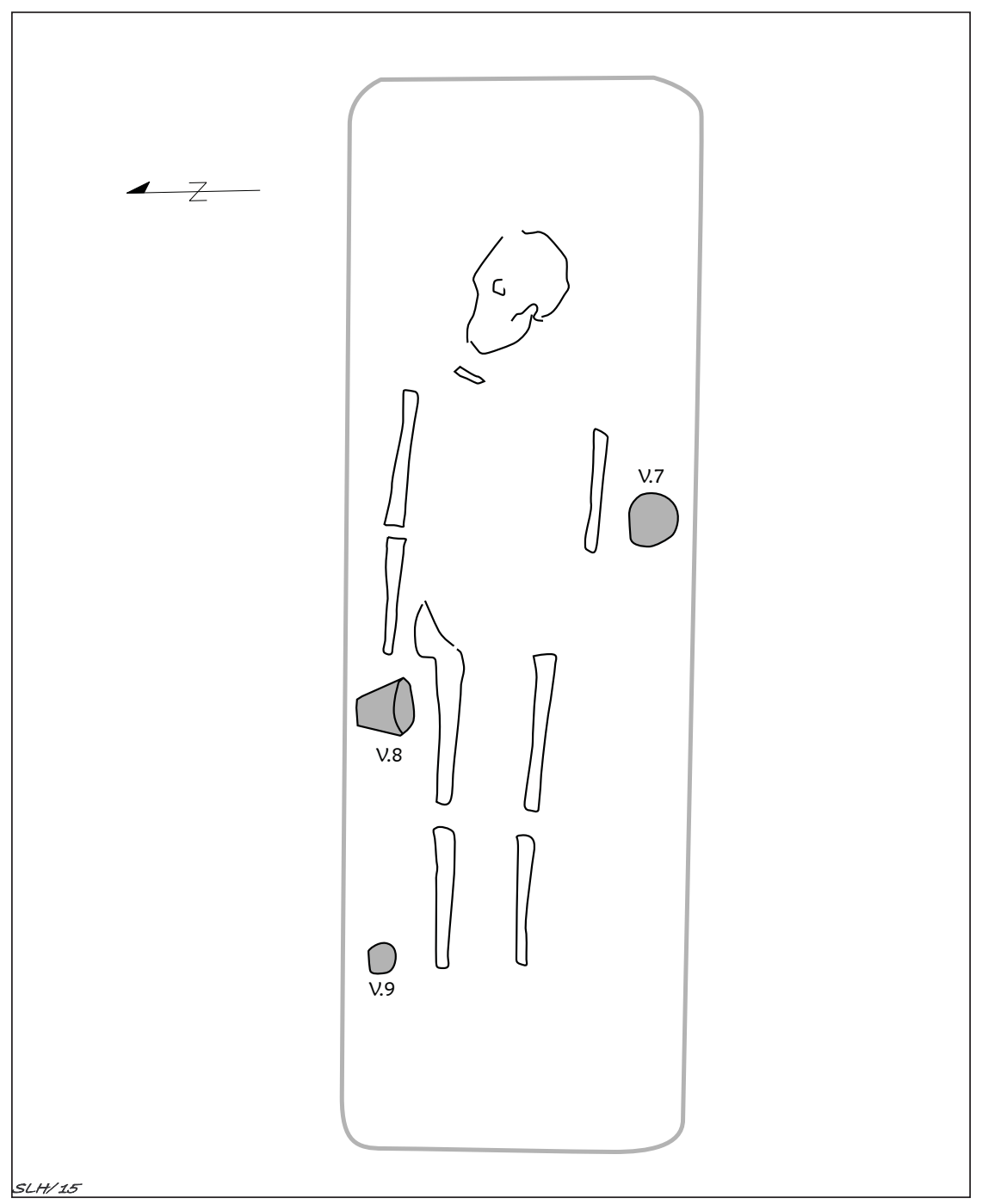

Figure 6. Burial $\mathrm{X}-3$ at the W. A. Ford site.

\section{Burial $X-6$}

Burial X-6 was probably an adolescent based on the size of the grave (see Table 1). Unlike the other burials in the W. A. Ford site cemetery, the deceased was laid out in an extended supine position with its head facing to the northeast (Figure 8; see also Figure 3); this burial was about $3 \mathrm{~m}$ to the southeast of Burial X-5. Two vessels were placed with this individual, an everted rim punctated jar (Vessel No. 14) by the left side of the head, and an engraved bowl (Vessel No. 15) by the upper right arm (Figure 8). A deposit of red ochre $1.3 \mathrm{~cm}$ thick had been packed in the bottom of Vessel No. 14 .

\section{Burial X-7}

The small size of the grave of Burial X-7 (see Table 1) suggests this is the burial of an adolescent or child. Associated with the burial was a single everted rim jar (Vessel No. 16) placed by the upper right arm (Figure 9). Burial X-7 is about $3 \mathrm{~m}$ north of Burial $\mathrm{X}-5$ (see Figure 3). 




Figure 7. Burial X-5 at the W. A. Ford site.

\section{Burial $X-8$}

Burial $\mathrm{X}-8$ is by the far the most distinctive of the burial features in the W. A. Ford site cemetery. This burial, about 3 m northeast of Burial X-7 (see Figure 3), has two adolescent or children lying next to each other in the grave (Figure 10). There were mussel shells in and near several of the ceramic vessels, as well as quartz pieces in the southwestern corner of the grave; Goldschmidt (1934:20) also noted that charcoal pieces were found throughout the burial fill. Three clusters of triangular arrow points had been placed in the grave, one cluster of seven by the right knee of Skeleton II and under Vessel No. 23, three others by the lower right leg of Skeleton I, and two points by the left leg of Skeleton I (Figure 10).

The ceramic vessels were placed by the head and shoulders of Skeleton I and the head, shoulders, and right leg of Skeleton II (see Figure 10). This includes a Ripley Engraved carinated bowl (Vessel No. 18; Goldschmidt labeled it No. 17 on his burial plan) by the left shoulder of Skeleton I, a plain bowl (Vessel No. 17, not in the TARL collections) by the left side of the head of Skeleton I, another Ripley Engraved carinated bowl (Vessel No. 19) between the heads of both skeletons, and a Wilder Engraved bottle (Vessel No. 20) near the mouth of Skeleton II. A shell-tempered Emory Punctated-Incised jar (Vessel No. 21) had been placed by the right hip of Skeleton II, next to a shell-tempered Simms Engraved carinated bowl (Vessel No. 


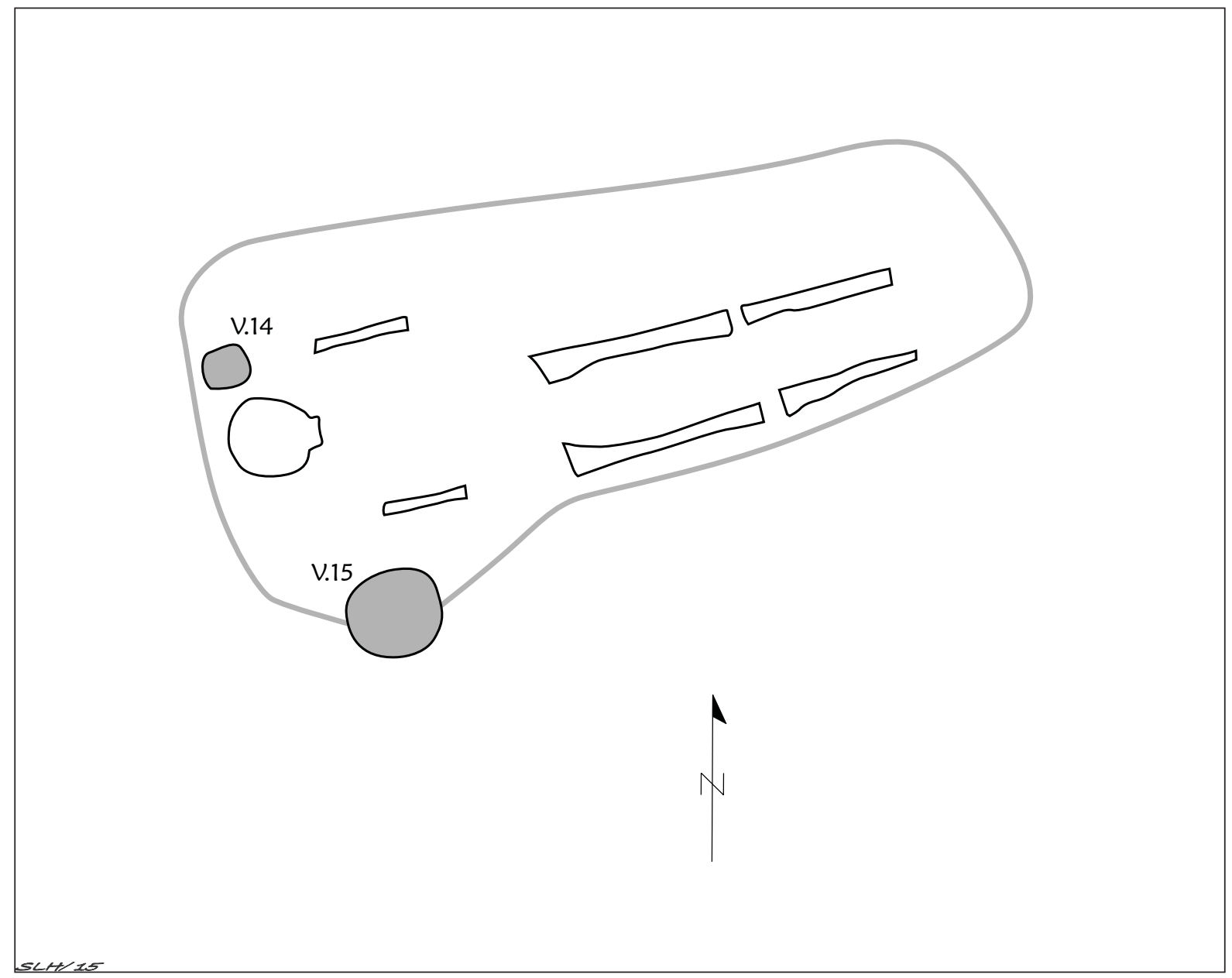

Figure 8. Burial X-6 at the W. A. Ford site.



Figure 9. Burial X-7 at the W. A. Ford site. 


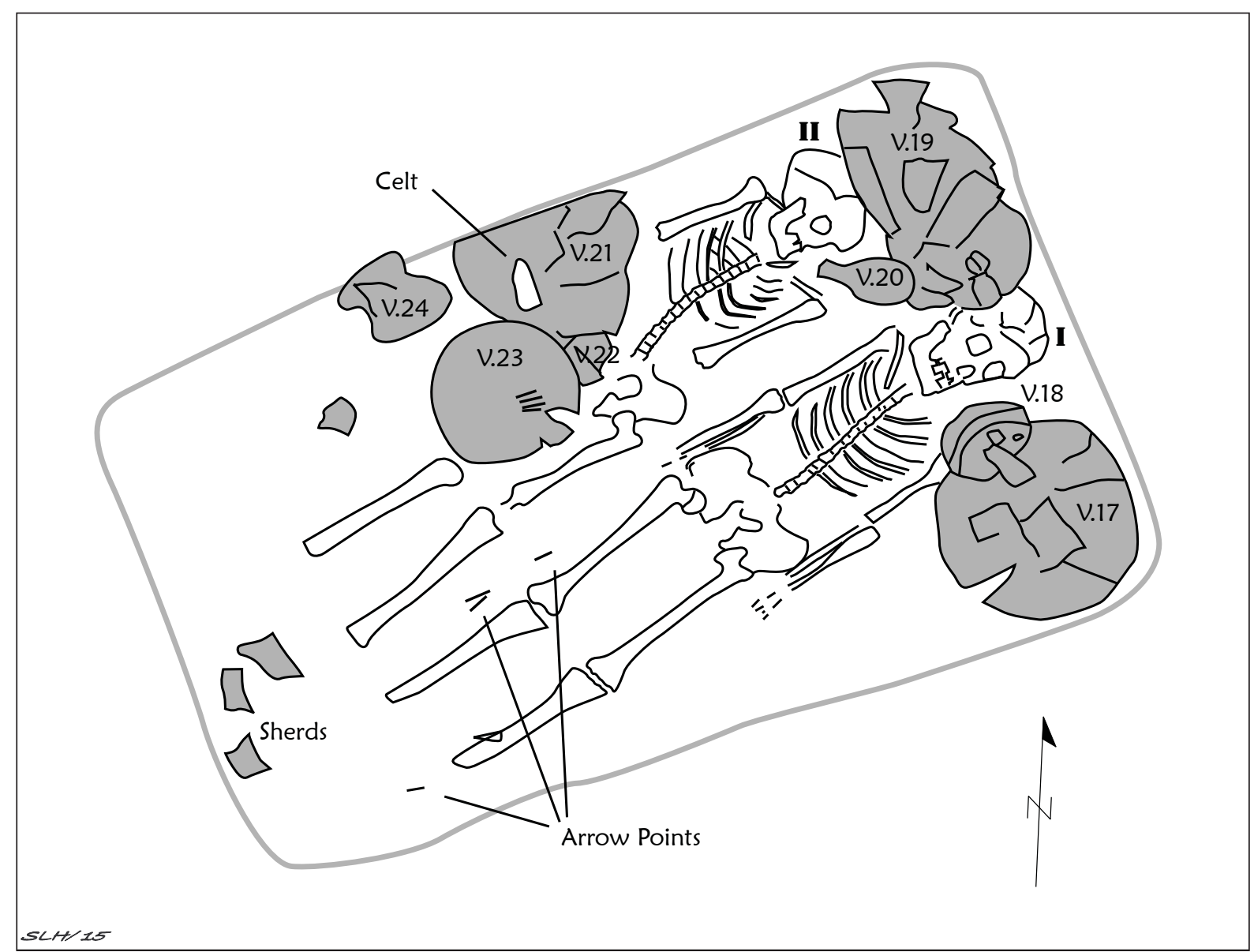

Figure 10. Burial $\mathrm{X}-8$ at the W. A. Ford site.

22) (see Figure 10); a celt was inside this vessel and the hand of Skeleton II was in the vessel (Goldschmidt 1934:20). A large plain carinated bowl (Vessel No. 23) rested atop the upper right leg of Skeleton II, and a La Rue Neck Banded jar (Vessel No. 24) was to its right.

\section{Burial $X-9$}

Burial X-9 is that of an adult lying in an extended supine position in a large burial pit (Figure 11). It was intrusive into an earlier burial, Burial $\mathrm{X}-10$. Burial $\mathrm{X}-9$ is ca. $1.5 \mathrm{~m}$ north of Burial $\mathrm{X}-8$, and is clearly related to it based on the character of the graves and their accompanying funerary offerings.

The funerary offerings for Burial X-9 were placed on both sides of the body (see Figure 11). Among the animal bones noted in the grave was a beaver incisor tooth (No. 49) by Vessel No. 48 near the right lower leg. Three arrow points (No. 50-52) were by the legs (Goldschmidt 1934:29).

A large Ripley Engraved carinated bowl (Vessel No. 39) was placed by the left side of the head of the deceased, with a Wilder Engraved bottle (Vessel No. 40) lying atop the upper left arm (see Figure 11). An Avery Engraved compound bowl (Vessel No. 41) rested by the lower left arm, with a red-slipped Simms Plain deep bowl (Vessel No. 42) near the upper left leg. Another large Ripley Engraved carinated bowl (Vessel No. 43) was by the lower right arm, and a plain carinated bowl (Vessel No. 44 or 45) rested over the deceased's abdomen (see Figure 11). Two jars - a La Rue Necked jar (Vessel No. 46) and an appliqued jar (Vessel No. 47) were placed alongside the upper right leg. Finally, a large Ripley Engraved carinated bowl (No. 48) had been placed to the right of the lower right leg and foot of the deceased (see Figure 11). 


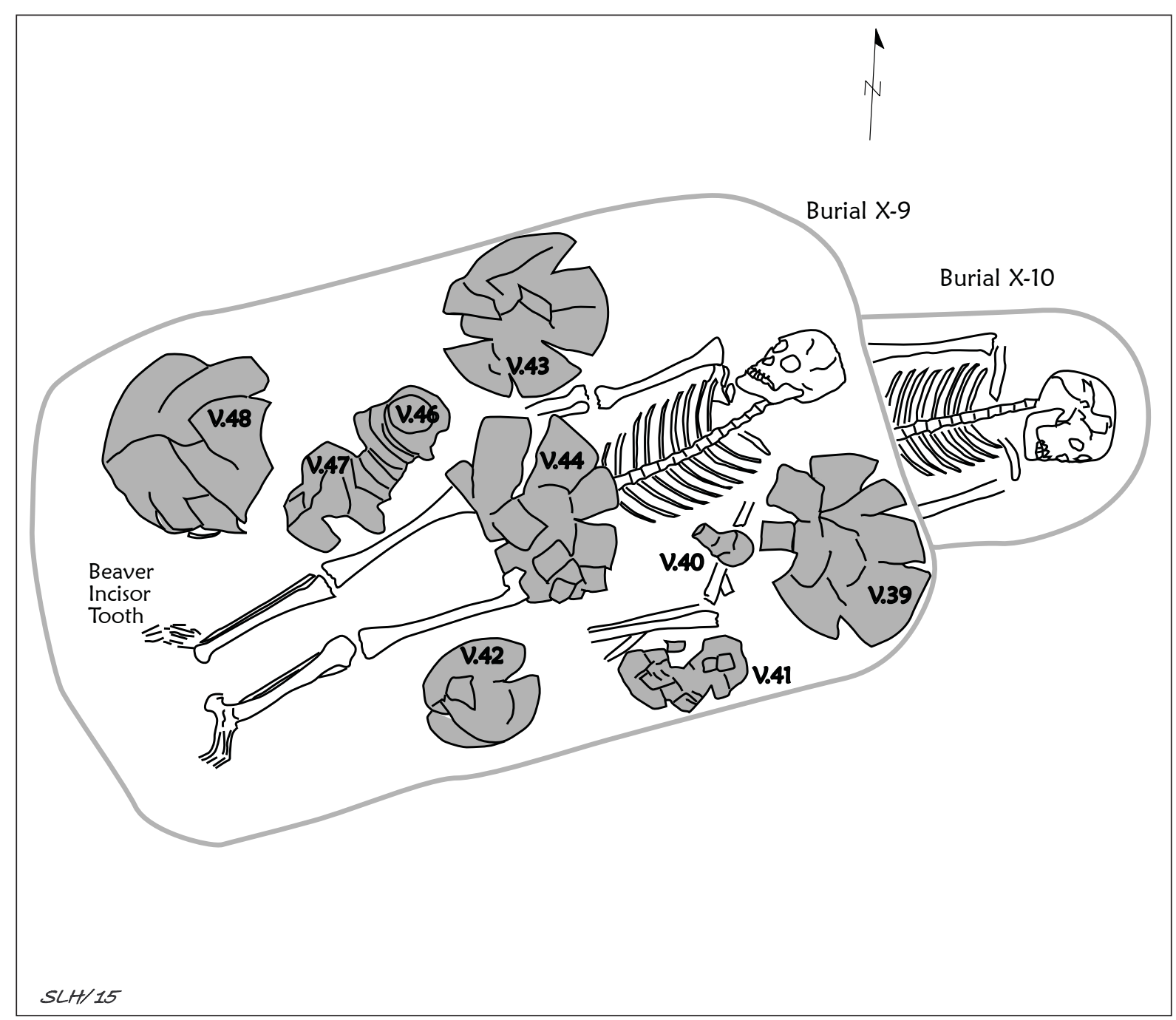

Figure 11. Burials $\mathrm{X}-9$ and $\mathrm{X}-10$ at the W. A. Ford site.

\section{Burial X-10}

Burial $\mathrm{X}-10$, also that of an adult, had been cut through at the mid-thoracic area of the body by Burial $X-9$, a later burial feature (see Figure 11). The remainder of Burial $X-10$ had been removed by the aboriginal excavation of the Burial $\mathrm{X}-9$ feature and there are no associated funerary offerings.

\section{Burial X-11}

The foot of this burial is about $0.6 \mathrm{~m}$ east of Burials $\mathrm{X}-8$ and $\mathrm{X}-9$ (see Figure 3); it is an adult placed in a large rectangular grave (Figure 12). A number of triangular arrow points had been placed by the upper right leg as well as along the left side of the deceased. A single bear canine tooth was in the northeastern part of the grave, but Goldschmidt (1934:34) did not plot its exact location on the burial plan. Goldschmidt (1934:33) also noted that there was a deposit of red clay in the central part of the south side of the grave.

A number of ceramic vessels were placed as funerary offerings in the grave of Burial $\mathrm{X}-11$. Among these is an engraved carinated bowl (Vessel No. 53) above and to the left of the left side of the head of the deceased, a Ripley Engraved carinated bowl (Vessel No. 54) by the upper right arm and shoulder, a very large Ripley Engraved compound bowl (Vessel No. 55) by the hip and the upper right leg, and a large plain carinated bowl (Vessel No. 56) intermixed with the aforementioned engraved compound bowl (see Figure 


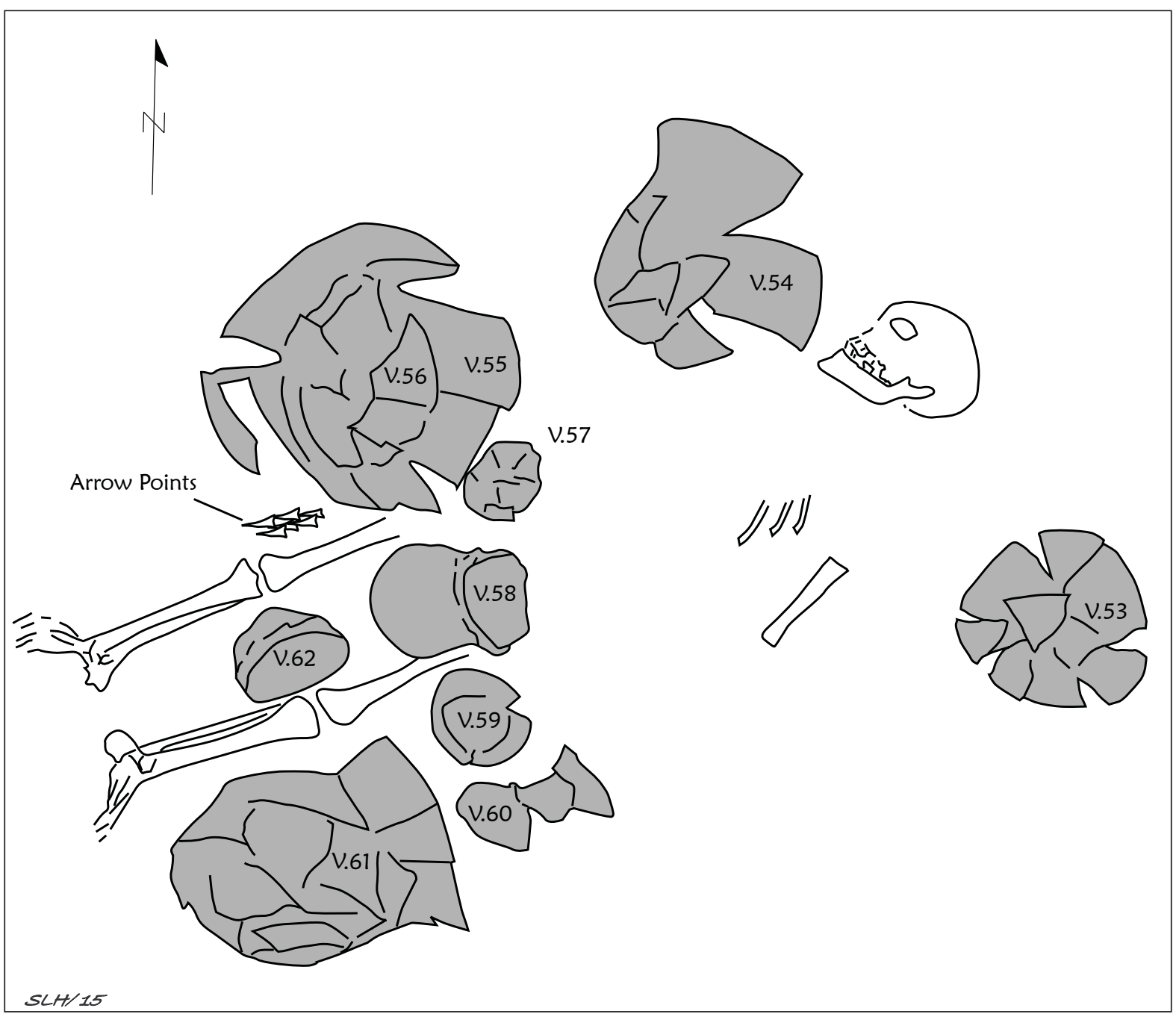

Figure 12. Burial $\mathrm{X}-11$ at the W. A. Ford site.

12). Another plain carinated bowl (Vessel No. 57) rested on the upper right leg, while an incised-punctated jar (Vessel No. 58) rested between the legs and on the stomach of the deceased. A shell-tempered engraved jar (Vessel No. 59) had been placed by the upper left leg, and next to it was a portion of a large tan vessel (No. 60) (see Figure 12). A very large La Rue Neck Banded jar (Vessel No. 61) rested by the upper and lower left legs of the deceased, and a Ripley Engraved carinated bowl (Vessel No. 62) had been placed between both legs, at the knees (see Figure 12).

\section{Funerary Vessels}

The vessel collections at TARL have 36 ceramic vessels from the W. A. Ford site. These vessels are funerary offerings in nine of the 11 burials excavated at the site, with a mean of 4.0 vessels per burial that have ceramic vessel offerings; the range is from one vessel (Burials $X-1, X-4$, and $X-7$ ) to as many as nine vessels (Burials $X-9$ and $X-11$ ); Burials $X-5$ and $X-10$ did not have any ceramic vessels. As will be discussed below in more detail, the ceramic vessels in the burials can be differentiated by temper, vessel form, and decorative elements into three distinct groups. These groups appear to have both cultural and temporal significance.

The first, and earliest, group includes the eight vessels from Burials $X-1$ to $X-4$; a mean of 2.0 vessels per burial. These are grog (50 percent), bone ( 25.0 percent), and grog-bone ( 25.0 percent) tempered vessels, 
including two jars, five bowls, and one carinated bowl. More than 62 percent of the vessels are plain, one has appliqued nodes, another has incised decorative elements (Canton Incised), and the last vessel in the group has incised-punctated decorative elements. Although there are no radiocarbon dates from these vessels, it is suspected that they are from early Caddo burials that predate ca. A.D. 1000; the absence of engraved vessels in this group is notable. Other burials likely associated with this group of interments are Burial X-5 and X-10.

The second group of vessels is comprised of three vessels from Burials $\mathrm{X}-6$ and $\mathrm{X}-7$; a mean of 1.5 vessels per burial. These vessels are grog (67 percent) and grog-bone (33 percent) tempered everted rim jars (67 percent) and bowls (33 percent). The vessels are decorated either with rows of punctates or have engraved elements featuring an SZ (see Gadus 2013:Figure 5). Although Gadus (2013:237) indicates that the SZ element on ceramic vessels was employed as early as the Early Caddo period, its occurrence together in a grave with an everted rim jar suggests these vessels and burials postdate ca. A.D. 1400; they may well be contemporaneous with the third group of burials and vessels, but radiocarbon dates on these burials and vessels would be necessary to confidently establish their temporal relationship.

The last, and third, group of vessels includes 25 vessels from Burials $X-8, X-9$, and $X-11$; these burials have a mean of 8.3 vessels as funerary offerings. These vessels are tempered with grog ( 72 percent), grogbone ( 8 percent), and shell (20 percent); the shell-tempered vessels were likely not manufactured locally, but were apparently manufactured by McCurtain phase Caddo potters living on the middle reaches of the Red River to the north of the W. A. Ford site. The vessels include jars ( 28 percent), bowls (4 percent), carinated bowls ( 52 percent), bottles ( 8 percent), and compound bowls ( 8 percent). The types represented in the shell-tempered vessels from these burials are Emory Punctated-Incised, Simms Engraved, Simms Plain, and Avery Engraved $(n=2)$; these are common McCurtain phase types (Perttula 2013:194 and Figures 1011). The grog and grog-bone-tempered vessels $(n=20)$ feature Titus phase types (Perttula 2013:Figures 12 and 13), including Ripley Engraved ( $\mathrm{n}=8$ vessels) carinated bowls and compound bowls, Wilder Engraved $(n=2)$ bottles, and La Rue Neck Banded $(n=3)$ jars. There are also four plain vessels, two incised-punctated and appliqued utility ware vessels, and a vessel with an unidentified engraved motif. The combination of grog, grog-bone, and shell-tempered vessels with a variety of decorative elements and motifs suggests they are from burials that date to the Titus phase of the Late Caddo period, from ca. A.D. 1430-1680. Because of the forms of Simms Engraved and Simms Plain vessels in Burials X-8 and X-9, it is possible to suggest that these burials and vessels date to the $17^{\text {th }}$ century A.D., and Burial $\mathrm{X}-11$ sometime before that age. 
SITE NAME OR SITE NUMBER: W. A. Ford (41TT2)

VESSEL NO.: 1, Burial X-1

VESSEL FORM: Bowl

NON-PLASTICS AND PASTE: grog

RIM AND LIP FORM: Direct rim and a rounded lip

CORE COLOR: F (fired in a reducing environment and cooled in the open air)

INTERIOR SURFACE COLOR: brown; fire clouds on the rim and body

EXTERIOR SURFACE COLOR: brown; fire clouds on the body and base

WALL THICKNESS (IN MM): rim, $5.0 \mathrm{~mm}$

INTERIOR SURFACE TREATMENT: smoothed

EXTERIOR SURFACE TREATMENT: smoothed

HEIGHT (IN CM): 7.6

ORIFICE DIAMETER (IN

CM): 10.2

DIAMETER AT BOTTOM OF RIM OR NECK (IN CM): N/A

BASE DIAMETER (IN CM) AND SHAPE OF BASE: 5.1; circular and rounded

ESTIMATED VOLUME (IN LITERS): 0.31

DECORATION (INCLUDING MOTIF AND ELEMENTS WHEN APPARENT): Plain (Figure 13)

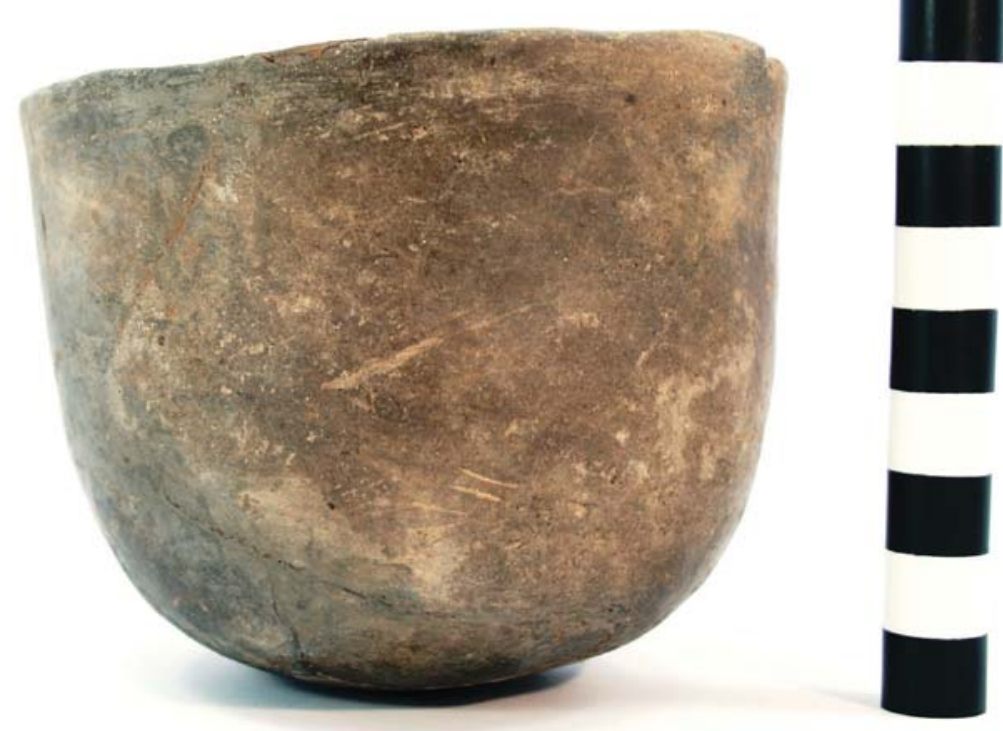

Figure 13. Plain bowl from Burial $\mathrm{X}-1$ at the W. A. Ford site.

PIGMENT USE AND LOCATION ON VESSEL: none

TYPE AND VARIETY (IF KNOWN): Unidentified plain ware 
SITE NAME OR SITE NUMBER: W. A. Ford (41TT2)

VESSEL NO.: 3, Burial X-2

VESSEL FORM: Bowl

NON-PLASTICS AND PASTE: grog and bone

RIM AND LIP FORM: Direct rim and rounded lip

CORE COLOR: A (fired and cooled in an oxidizing environment)

INTERIOR SURFACE COLOR: reddish-brown; fire clouds on the base

EXTERIOR SURFACE COLOR: reddish-brown; fire clouds on the base

WALL THICKNESS (IN MM):

rim, $4.9 \mathrm{~mm}$

INTERIOR SURFACE

TREATMENT: smoothed

EXTERIOR SURFACE

TREATMENT: none

HEIGHT (IN CM): 3.6

ORIFICE DIAMETER (IN CM):

7.8

DIAMETER AT BOTTOM OF

RIM OR NECK (IN CM): N/A

BASE DIAMETER (IN CM)

AND SHAPE OF BASE: 5.1;

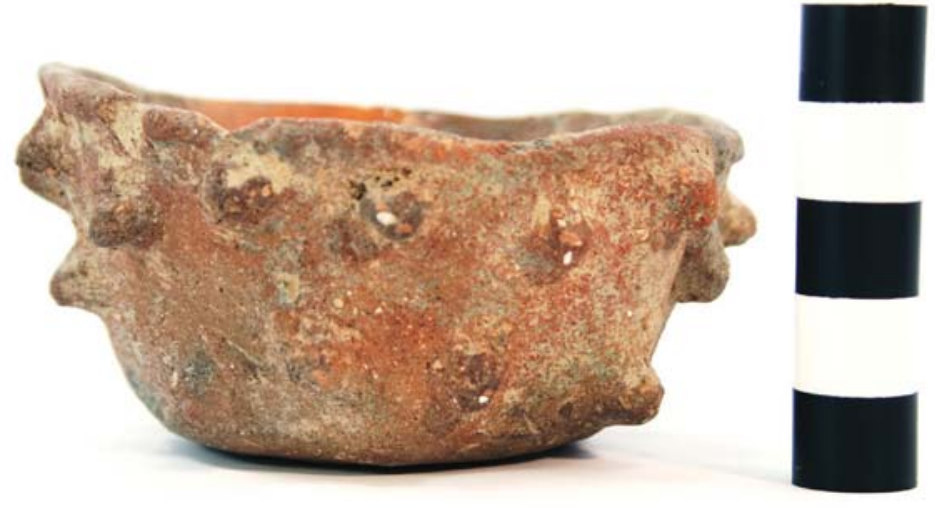

Figure 14. Noded bowl from Burial X-2 at the W. A. Ford site.

circular and flat

ESTIMATED VOLUME (IN LITERS): 0.11

DECORATION (INCLUDING MOTIF AND ELEMENTS WHEN APPARENT): There are three rows of appliqued nodes on the vessel exterior (Figure 14). The nodes range from $6.2-7.5 \mathrm{~mm}$ in diameter.

PIGMENT USE AND LOCATION ON VESSEL: none

TYPE AND VARIETY (IF KNOWN): Unidentified, but may be related to the Moore Noded type 
SITE NAME OR SITE NUMBER: W. A. Ford (41TT2)

VESSEL NO.: 4, Burial X-2

VESSEL FORM: Bowl with a notched or cut lip (Figure 15)

NON-PLASTICS AND PASTE: grog

RIM AND LIP FORM: Direct rim and rounded lip

CORE COLOR: F (fired in a reducing environment and cooled in the open air)

INTERIOR SURFACE COLOR: dark yellowish-brown; fire clouds on the rim, body, and base

EXTERIOR SURFACE COLOR: yellowish-brown; fire clouds on the rim, body, and base

WALL THICKNESS (IN MM): rim, $5.0 \mathrm{~mm}$

INTERIOR SURFACE TREATMENT: smoothed

EXTERIOR SURFACE TREATMENT: smoothed

HEIGHT (IN CM): 2.5

ORIFICE DIAMETER

(IN CM): 10.7

DIAMETER AT BOTTOM

OF RIM OR

NECK (IN CM): N/A

BASE DIAMETER

(IN CM) AND SHAPE OF

BASE: 6.3; circular and flat

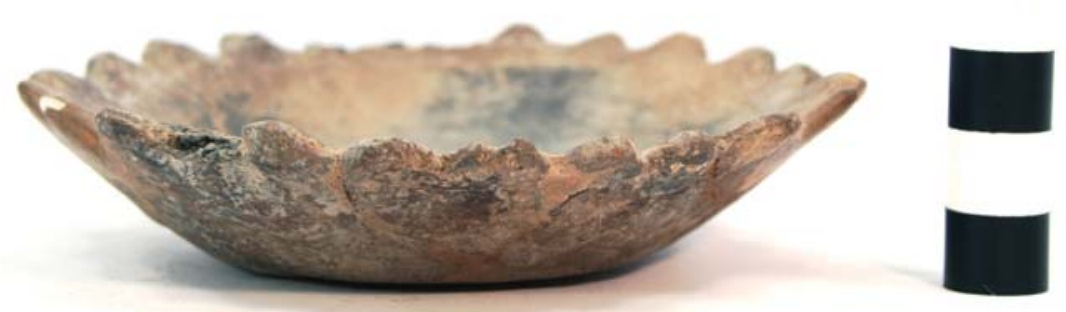

ESTIMATED VOLUME

(IN LITERS): 0.11

Figure 15. Notched plain bowl from Burial X-2 at the W. A. Ford site.

DECORATION (INCLUDING MOTIF AND ELEMENTS WHEN APPARENT): Plain (Figure 15)

PIGMENT USE AND LOCATION ON VESSEL: none

TYPE AND VARIETY (IF KNOWN): Unidentified plain ware 
SITE NAME OR SITE NUMBER: W. A. Ford (41TT2)

VESSEL NO.: 5, Burial X-2

VESSEL FORM: grog

NON-PLASTICS AND PASTE: Carinated bowl

RIM AND LIP FORM: Inverted rim and rounded lip

CORE COLOR: $\mathrm{G}$ (fired in a reducing environment and cooled in the open air)

INTERIOR SURFACE COLOR: dark grayish-brown

EXTERIOR SURFACE COLOR: brown; fire clouds on the body and base

WALL THICKNESS (IN MM): rim, $5.7 \mathrm{~mm}$

INTERIOR SURFACE TREATMENT: none

EXTERIOR SURFACE TREATMENT: smoothed

HEIGHT (IN CM):

8.3

ORIFICE

DIAMETER (IN

CM): 11.5

DIAMETER AT

BOTTOM OF RIM

OR NECK (IN CM):

12.4

BASE DIAMETER

(IN CM) AND

SHAPE OF BASE:

8.3; circular and flat

ESTIMATED

VOLUME (IN

LITERS): 0.57

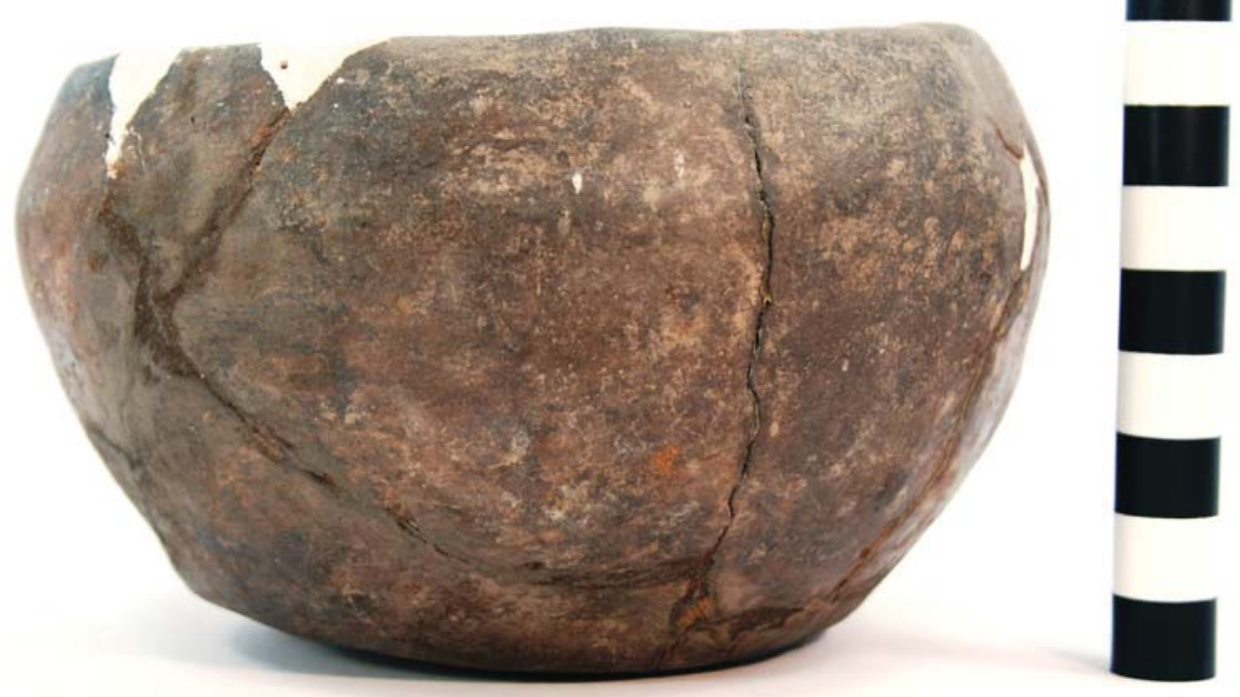

Figure 16. Plain carinated bowl, Burial 2, Vessel 5.

DECORATION

(INCLUDING

MOTIF AND ELEMENTS WHEN APPARENT): Plain (Figure 16)

PIGMENT USE AND LOCATION ON VESSEL: none

TYPE AND VARIETY (IF KNOWN): Unidentified plain ware 
SITE NAME OR SITE NUMBER: W. A. Ford (41TT2)

VESSEL NO.: 7, Burial X-3

VESSEL FORM: globular Bowl

NON-PLASTICS AND PASTE: grog and bone

RIM AND LIP FORM: Direct rim and rounded lip

CORE COLOR: $\mathrm{F}$ (fired in a reducing environment and cooled in the open air)

INTERIOR SURFACE COLOR: yellowish-brown; fire clouds on rim and body

EXTERIOR SURFACE COLOR: yellowish-brown; fire clouds on the rim and body

WALL THICKNESS (IN MM): rim, $4.8 \mathrm{~mm}$

INTERIOR SURFACE TREATMENT: smoothed

EXTERIOR SURFACE

TREATMENT: smoothed

HEIGHT (IN CM): 7.8

ORIFICE DIAMETER (IN CM):

10.8

DIAMETER AT BOTTOM OF

RIM OR NECK (IN CM): 10.8

BASE DIAMETER (IN CM)

AND SHAPE OF BASE: 5.7;

circular and rounded

ESTIMATED VOLUME (IN

LITERS): 0.34

DECORATION (INCLUDING

MOTIF AND ELEMENTS

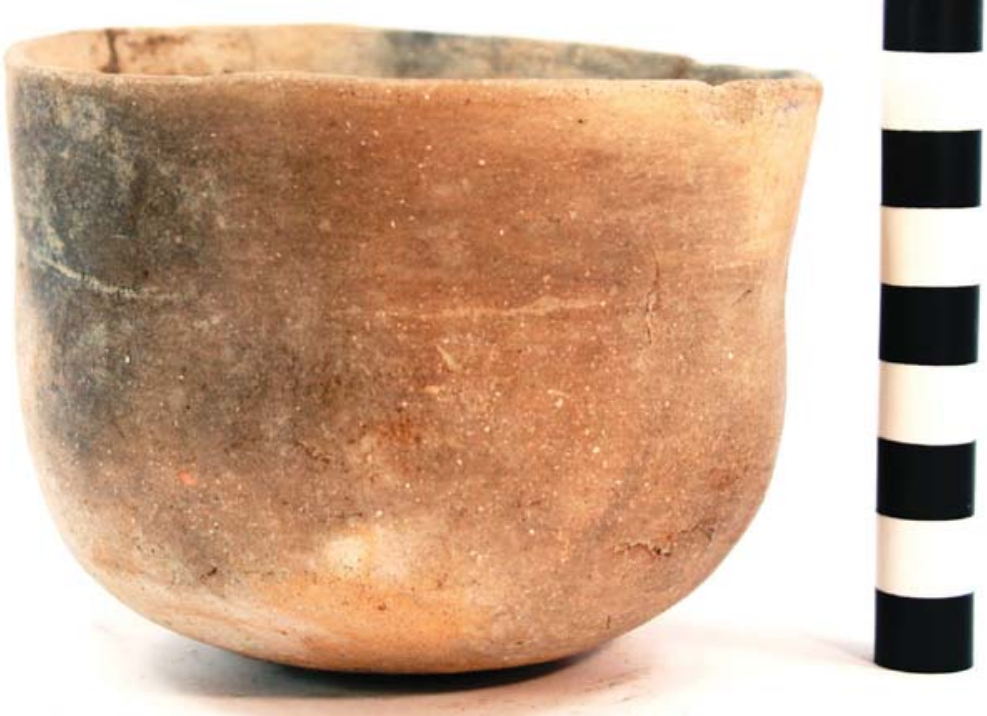

Figure 17. Plain bowl from the W. A. Ford site. WHEN APPARENT): Plain (Figure 17)

PIGMENT USE AND LOCATION ON VESSEL: none

TYPE AND VARIETY (IF KNOWN): Unidentified plain ware 
SITE NAME OR SITE NUMBER: W. A. Ford (41TT2)

VESSEL NO.: 8, Burial X-3

VESSEL FORM: Jar

NON-PLASTICS AND PASTE: grog

RIM AND LIP FORM: Direct rim and rounded lip

CORE COLOR: $\mathrm{F}$ (fired in a reducing environment and cooled in the open air)

INTERIOR SURFACE COLOR: yellowish-brown; fire clouds on the rim and upper body

EXTERIOR SURFACE COLOR: dark yellowish-brown; fire clouds on the rim, body, and base

WALL THICKNESS (IN MM): rim, $5.2 \mathrm{~mm}$

INTERIOR SURFACE TREATMENT: smoothed

EXTERIOR SURFACE TREATMENT:

smoothed on the lower body

HEIGHT (IN CM): 12.8

ORIFICE DIAMETER (IN CM): 12.1

DIAMETER AT BOTTOM OF RIM OR

NECK (IN CM): 12.1

BASE DIAMETER (IN CM) AND

SHAPE OF BASE: 8.9; circular and flat

ESTIMATED VOLUME (IN LITERS):

0.93

DECORATION (INCLUDING MOTIF AND ELEMENTS WHEN APPARENT):

There are four upper and lower concentric semi-circles (defined by four incised lines) that are filled with rows of tool punctates (Figure 18).

PIGMENT USE AND



Figure 18. Canton Incised jar from Burial X-3 at the W. A. Ford site.

TYPE AND VARIETY (IF KNOWN): Canton Incised 
SITE NAME OR SITE NUMBER: W. A. Ford (41TT2)

VESSEL NO.: 9, Burial X-3

VESSEL FORM: Jar

NON-PLASTICS AND PASTE: bone

RIM AND LIP FORM: Direct rim and rounded lip

CORE COLOR: F (fired in a reducing environment and cooled in the open air)

INTERIOR SURFACE COLOR: yellowish-brown; fire clouds on the rim

EXTERIOR SURFACE COLOR: yellowish-brown; fire clouds on the rim, body, and base

WALL THICKNESS (IN MM): rim, 5.9 mm

INTERIOR SURFACE TREATMENT: smoothed on the rim

EXTERIOR SURFACE TREATMENT: none

HEIGHT (IN CM): 10.1

ORIFICE DIAMETER (IN

$\mathrm{CM}): 10.4$

DIAMETER AT BOTTOM OF RIM OR NECK (IN CM): 10.4

BASE DIAMETER (IN CM) AND SHAPE OF BASE: 5.1 ; circular and concave

ESTIMATED VOLUME (IN LITERS): 0.63

DECORATION (INCLUDING MOTIF AND ELEMENTS WHEN APPARENT): The rim has a continuous series of vertical incised lines above a row of linear tool punctations at the rim-body juncture

(Figure 19).

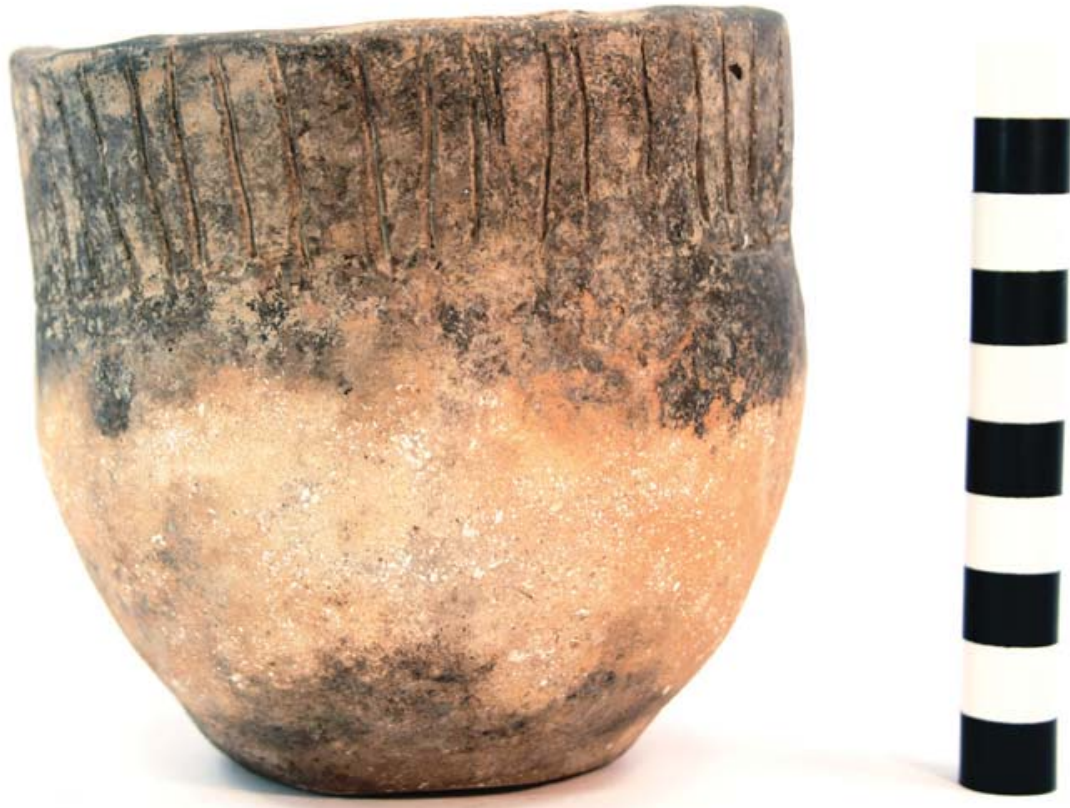

Figure 19. Incised-punctated jar from Burial X-3 at the W. A. Ford site.

PIGMENT USE AND LOCATION ON VESSEL: none

TYPE AND VARIETY (IF KNOWN): Unidentified utility ware 
SITE NAME OR SITE NUMBER: W. A. Ford (41TT2)

VESSEL NO.: 10, Burial X-4

VESSEL FORM: Bowl

NON-PLASTICS AND PASTE: bone

RIM AND LIP FORM: Inverted rim and flat lip

CORE COLOR: $\mathrm{F}$ (fired in a reducing environment and cooled in the open air)

INTERIOR SURFACE COLOR: dark reddish-brown

EXTERIOR SURFACE COLOR: dark reddish-brown; fire clouds on the rim, body, and base

WALL THICKNESS (IN MM): rim, $6.3 \mathrm{~mm}$

INTERIOR SURFACE

TREATMENT: none

EXTERIOR SURFACE

TREATMENT: smoothed

HEIGHT (IN CM): 11.5

ORIFICE DIAMETER

(IN CM): 9.5

DIAMETER AT

BOTTOM OF RIM OR

NECK (IN CM): N/A

BASE DIAMETER (IN CM) AND SHAPE OF

BASE: 8.1 ; circular and flat

ESTIMATED VOLUME

(IN LITERS): 0.40

DECORATION

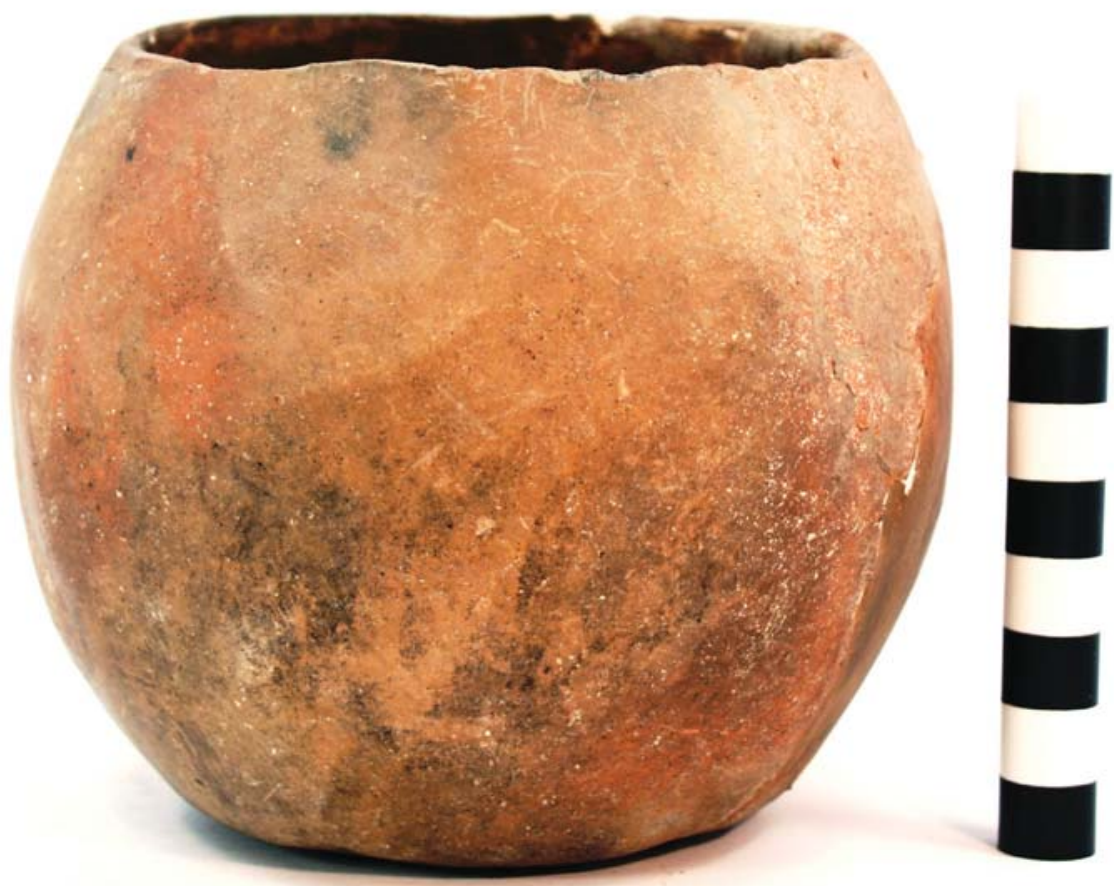

Figure 20. Plain bowl from Burial X-4 at the W. A. Ford site.

(INCLUDING MOTIF

AND ELEMENTS WHEN

APPARENT): Plain (Figure 20)

PIGMENT USE AND LOCATION ON VESSEL: none

TYPE AND VARIETY (IF KNOWN): Unidentified plain ware 
SITE NAME OR SITE NUMBER: W. A. Ford (41TT2)

VESSEL NO.: 14, Burial X-6

VESSEL FORM: Jar with a short rim

NON-PLASTICS AND PASTE: grog

RIM AND LIP FORM: Everted rim and rounded lip

CORE COLOR: $\mathrm{G}$ (fired in a reducing environment and cooled in the open air)

INTERIOR SURFACE COLOR: very dark grayish-brown

EXTERIOR SURFACE COLOR: yellowish-brown; fire clouds on the rim, body, and base

WALL THICKNESS (IN MM): rim, $6.2 \mathrm{~mm}$

INTERIOR SURFACE

TREATMENT: none

EXTERIOR SURFACE

TREATMENT: none

HEIGHT (IN CM): 11.5

ORIFICE DIAMETER (IN

CM): 10.3

DIAMETER AT BOTTOM OF

RIM OR NECK (IN CM): 10.2

BASE DIAMETER (IN CM) AND SHAPE OF BASE: 7.6; circular and flat

ESTIMATED VOLUME (IN

LITERS): 0.71

DECORATION (INCLUDING MOTIF AND ELEMENTS

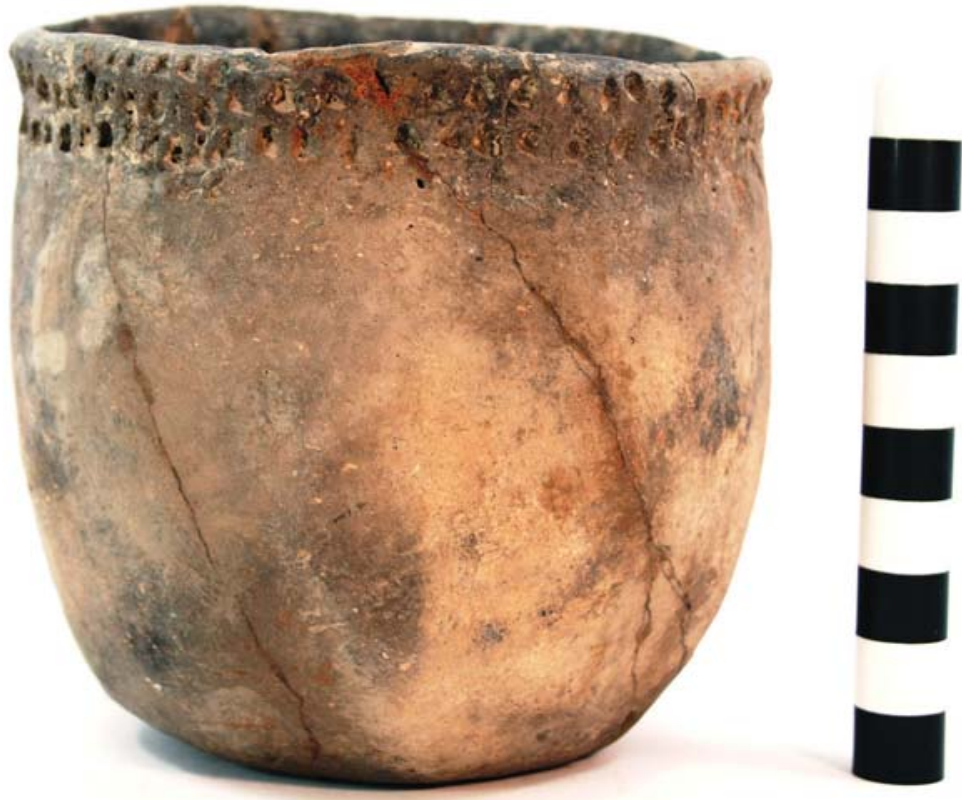

Figure 21. Mockingbird Punctated jar from Burial X-6 at the W. A. Ford site.

WHEN APPARENT): two

closely-spaced rows of tool punctates on the vessel rim (Figure 21)

PIGMENT USE AND LOCATION ON VESSEL: none

TYPE AND VARIETY (IF KNOWN): Mockingbird Punctated 
SITE NAME OR SITE NUMBER: W. A. Ford (41TT2)

VESSEL NO.: 15, Burial X-6

VESSEL FORM: Bowl

NON-PLASTICS AND PASTE: grog

RIM AND LIP FORM: Direct rim and rounded lip

CORE COLOR: $\mathrm{F}$ (fired in a reducing environment and cooled in the open air)

INTERIOR SURFACE COLOR: dark yellowish-brown

EXTERIOR SURFACE COLOR: dark yellowish-brown

WALL THICKNESS (IN

MM): rim, $5.2 \mathrm{~mm}$

INTERIOR SURFACE

TREATMENT: none

EXTERIOR SURFACE

TREATMENT: smoothed

HEIGHT (IN CM): 9.0

ORIFICE DIAMETER

(IN CM): 15.4

DIAMETER AT

BOTTOM OF RIM OR

NECK (IN CM): N/A

BASE DIAMETER (IN

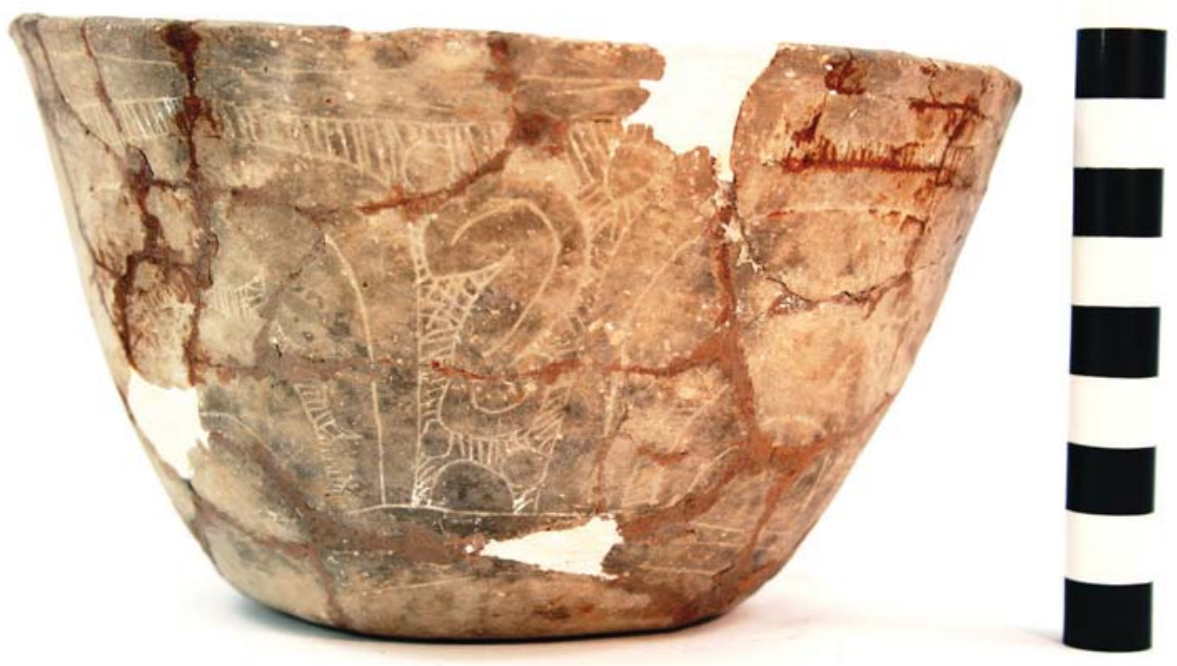

Figure 22. cf. Ripley Engraved bowl from Burial X-6 at the W. A. Ford site.

CM) AND SHAPE OF

BASE: 7.7; circular and flat

ESTIMATED VOLUME (IN LITERS): 0.56

DECORATION (INCLUDING MOTIF AND ELEMENTS WHEN APPARENT): The bowl has an engraved panel defined by horizontal engraved lines and an upper horizontal zone filled with vertical engraved lines (Figure 22). There are four repeated semi-circular engraved elements, with an inner hatched semi-circular zone, that are divided by brackets with negative circles, semi-circles, and negative $\mathrm{S}$-shaped or SZ elements. These elements are demarcated by vertical and diagonal hatched engraved lines and one area of cross-hatched lines (Figure 22).

PIGMENT USE AND LOCATION ON VESSEL: none

TYPE AND VARIETY (IF KNOWN): cf. Ripley Engraved 
SITE NAME OR SITE NUMBER: W. A. Ford (41TT2)

VESSEL NO.: 16, Burial X-7

VESSEL FORM: Jar with short rim

NON-PLASTICS AND PASTE: grog and bone

RIM AND LIP FORM: Everted rim and rounded lip

CORE COLOR: $\mathrm{F}$ (fired in a reducing environment and cooled in the open air)

INTERIOR SURFACE COLOR: brown; fire clouds on the body

EXTERIOR SURFACE COLOR: brown; fire clouds on the body and base; organic residue on the body

WALL THICKNESS (IN MM): rim, 5.3

$\mathrm{mm}$; body, $6.7 \mathrm{~mm}$

INTERIOR SURFACE TREATMENT: smoothed

EXTERIOR SURFACE TREATMENT: smoothed on the body

HEIGHT (IN CM): 16.5

ORIFICE DIAMETER (IN CM): 12.7

DIAMETER AT BOTTOM OF RIM

OR NECK (IN CM): 12.4

BASE DIAMETER (IN CM) AND

SHAPE OF BASE: 8.7; circular and rounded

ESTIMATED VOLUME (IN LITERS): 1.89

DECORATION (INCLUDING MOTIF AND ELEMENTS WHEN APPARENT): There are four horizontal rows of tool punctations on the rim

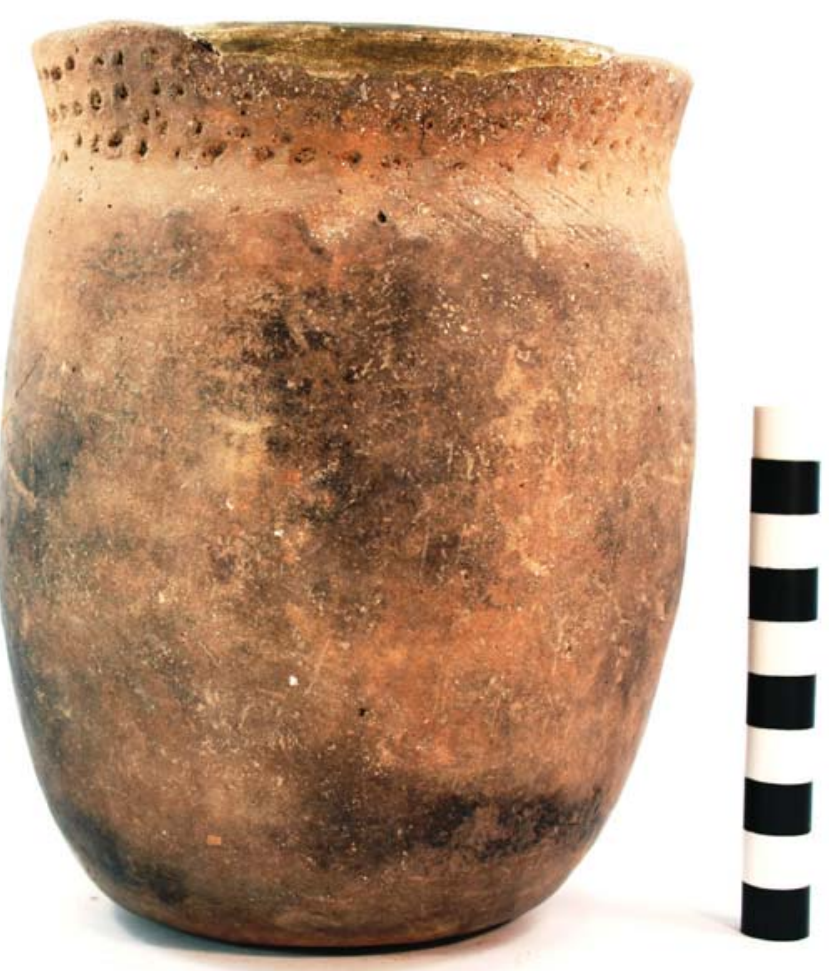

Figure 23. Mockingbird Punctated jar from Burial X-7 at the W. A. Ford site.

(Figure 23).

PIGMENT USE AND LOCATION ON VESSEL: none

TYPE AND VARIETY (IF KNOWN): Mockingbird Punctated 
SITE NAME OR SITE NUMBER: W. A. Ford (41TT2)

VESSEL NO.: 18, Burial X-8

VESSEL FORM: Carinated bowl

NON-PLASTICS AND PASTE: grog

RIM AND LIP FORM: Direct rim, and a rounded, exterior folded lip

CORE COLOR: $\mathrm{F}$ (fired in a reducing environment and cooled in the open air)

INTERIOR SURFACE COLOR: red

EXTERIOR SURFACE COLOR: red

WALL THICKNESS (IN

MM): rim, $6.4 \mathrm{~mm}$

INTERIOR SURFACE

TREATMENT: smoothed

EXTERIOR SURFACE

TREATMENT: burnished

HEIGHT (IN CM): 10.2

ORIFICE DIAMETER (IN

CM): 13.5

DIAMETER AT BOTTOM

OF RIM OR NECK (IN CM):

13.5

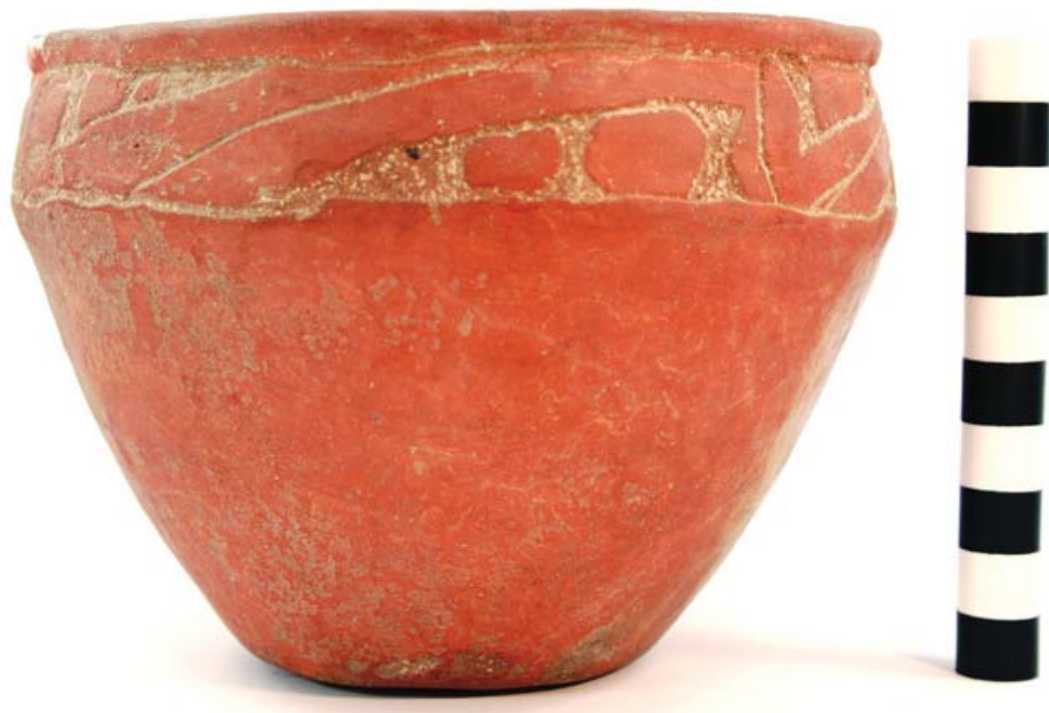

BASE DIAMETER (IN CM) AND SHAPE OF BASE: 6.4 ; circular and flat

Figure 24. Ripley Engraved, var. Carpenter carinated bowl from Burial $\mathrm{X}-8$ at the W. A. Ford site.

ESTIMATED VOLUME (IN

LITERS): 0.83

DECORATION (INCLUDING MOTIF AND ELEMENTS WHEN APPARENT): Interior and exterior redslipped. The exterior rim panel has a continuous scroll engraved motif repeated four times around the vessel (Figure 24). The upper and lower scroll fill zones have negative ovals defined by excised brackets and triangle elements.

PIGMENT USE AND LOCATION ON VESSEL: none

TYPE AND VARIETY (IF KNOWN): Ripley Engraved, var. Carpenter 
SITE NAME OR SITE NUMBER: W. A. Ford (41TT2)

VESSEL NO.: 19, Burial X-8

VESSEL FORM: Carinated bowl

NON-PLASTICS AND PASTE: grog

RIM AND LIP FORM: Inverted rim and rounded, exterior folded lip

CORE COLOR: $\mathrm{G}$ (fired in a reducing environment and cooled in the open air)

INTERIOR SURFACE COLOR: grayish-brown

EXTERIOR SURFACE COLOR:

brown

WALL THICKNESS (IN MM):

rim, $7.8 \mathrm{~mm}$

INTERIOR SURFACE

TREATMENT: smoothed

EXTERIOR SURFACE

TREATMENT: burnished

HEIGHT (IN CM): 17.8

ORIFICE DIAMETER (IN CM):

24.3

DIAMETER AT BOTTOM OF

RIM OR NECK (IN CM): 24.6

BASE DIAMETER (IN CM)

AND SHAPE OF BASE: 8.9;

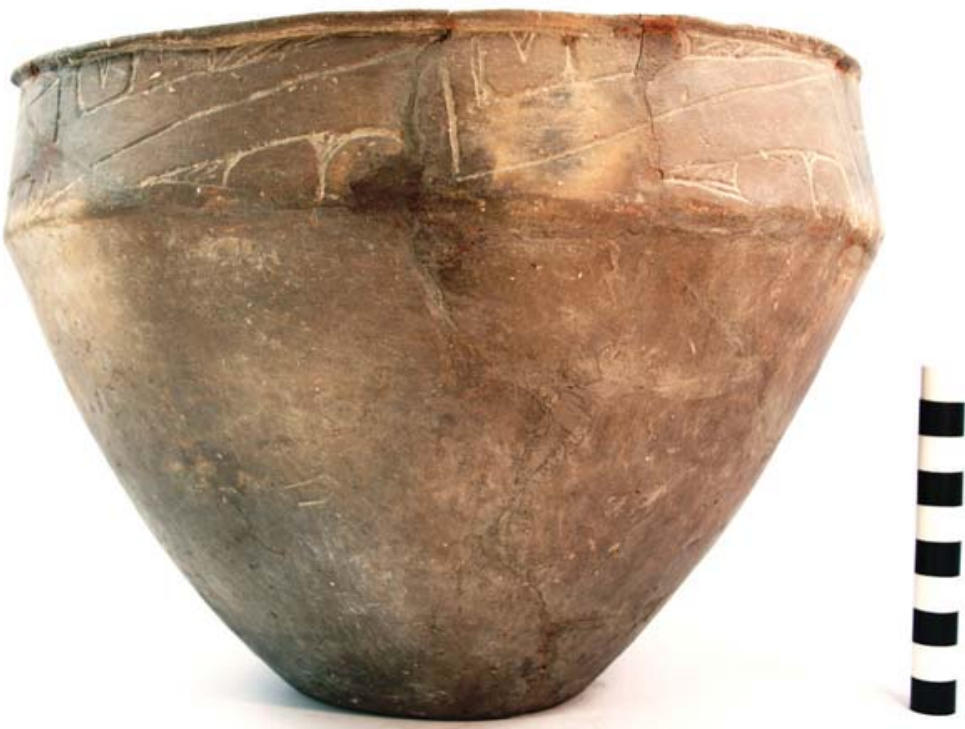

Figure 25. Ripley Engraved, var. Carpenter carinated bowl from Burial X-8 at the W. A. Ford site.

circular and flat

ESTIMATED VOLUME (IN LITERS): 3.9

DECORATION (INCLUDING MOTIF AND ELEMENTS WHEN APPARENT): The rim panel has an engraved continuous scroll motif repeated seven times around the vessel (Figure 25). The upper and lower scroll fill zones have hatched triangular areas and negative ovals. These ovals are either undecorated, or have a vertical engraved line, a curvilinear line with excised triangle, a hatched triangle, or a curvilinear excised line and a small curvilinear excised hook (Figure 25).

PIGMENT USE AND LOCATION ON VESSEL: none

TYPE AND VARIETY (IF KNOWN): Ripley Engraved, var. Carpenter 
SITE NAME OR SITE NUMBER: W. A. Ford (41TT2)

VESSEL NO.: 20, Burial X-8

VESSEL FORM: Bottle

NON-PLASTICS AND PASTE: grog

RIM AND LIP FORM: Missing

CORE COLOR: B (fired and cooled in a reducing environment)

INTERIOR SURFACE COLOR: very dark grayish-brown

EXTERIOR SURFACE COLOR:

black; fire clouds on the rim, body, and base

WALL THICKNESS (IN MM): neck, $6.7 \mathrm{~mm}$

INTERIOR SURFACE

TREATMENT: none

EXTERIOR SURFACE

TREATMENT: burnished

HEIGHT (IN CM): 15.3+

ORIFICE DIAMETER (IN CM): 3.4

DIAMETER AT BOTTOM OF RIM OR NECK (IN CM): 4.8; maximum body diameter is $8.7 \mathrm{~cm}$

BASE DIAMETER (IN CM) AND

SHAPE OF BASE: 6.4 ; circular and flat

ESTIMATED VOLUME (IN LITERS): $0.39+$

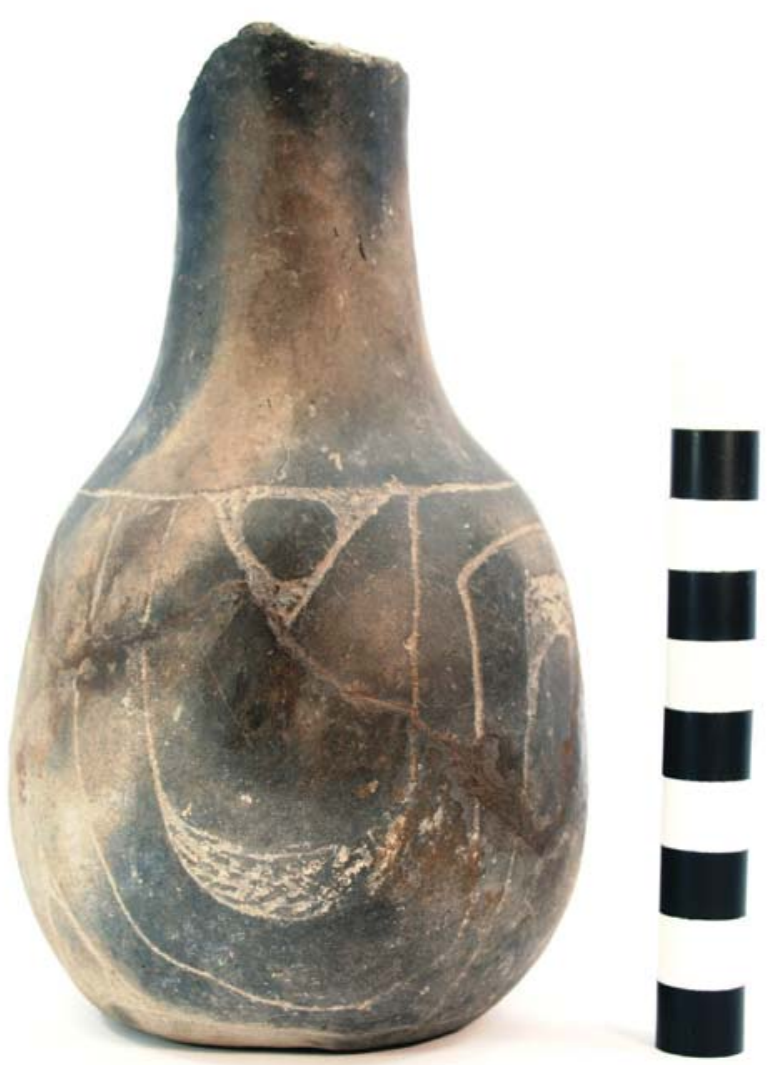

Figure 26. cf. Wilder Engraved bottle from Burial $\mathrm{X}-8$ at the W. A. Ford site.

DECORATION (INCLUDING MOTIF AND ELEMENTS WHEN APPARENT): The vessel body has an engraved panel defined by upper and lower horizontal engraved lines. There are four semi-circular engraved elements with curvilinear excised areas, excised triangles, and triangle elements with excised corners and a central negative oval (Figure 26). The excised triangles with negative ovals also occur as pendant triangles on the upper and lower panel lines.

PIGMENT USE AND LOCATION ON VESSEL: none

TYPE AND VARIETY (IF KNOWN): cf. Wilder Engraved 
SITE NAME OR SITE NUMBER: W. A. Ford (41TT2)

VESSEL NO.: 21, Burial X-8

VESSEL FORM: Jar

NON-PLASTICS AND PASTE: shell

RIM AND LIP FORM: Everted rim and rounded lip

CORE COLOR: $\mathrm{F}$ (fired in a reducing environment and cooled in the open air)

INTERIOR SURFACE COLOR: reddishbrown; fire clouds on the rim and body

EXTERIOR SURFACE COLOR: reddishbrown; fire clouds on the rim and body

WALL THICKNESS (IN MM): rim, 4.9 mm

INTERIOR SURFACE TREATMENT: smoothed

EXTERIOR SURFACE TREATMENT: smoothed on the body

HEIGHT (IN CM): 26.0

ORIFICE DIAMETER (IN CM): 17.1

DIAMETER AT BOTTOM OF RIM OR NECK (IN CM): 16.5

BASE DIAMETER (IN CM) AND SHAPE OF BASE: 10.2; circular and rounded

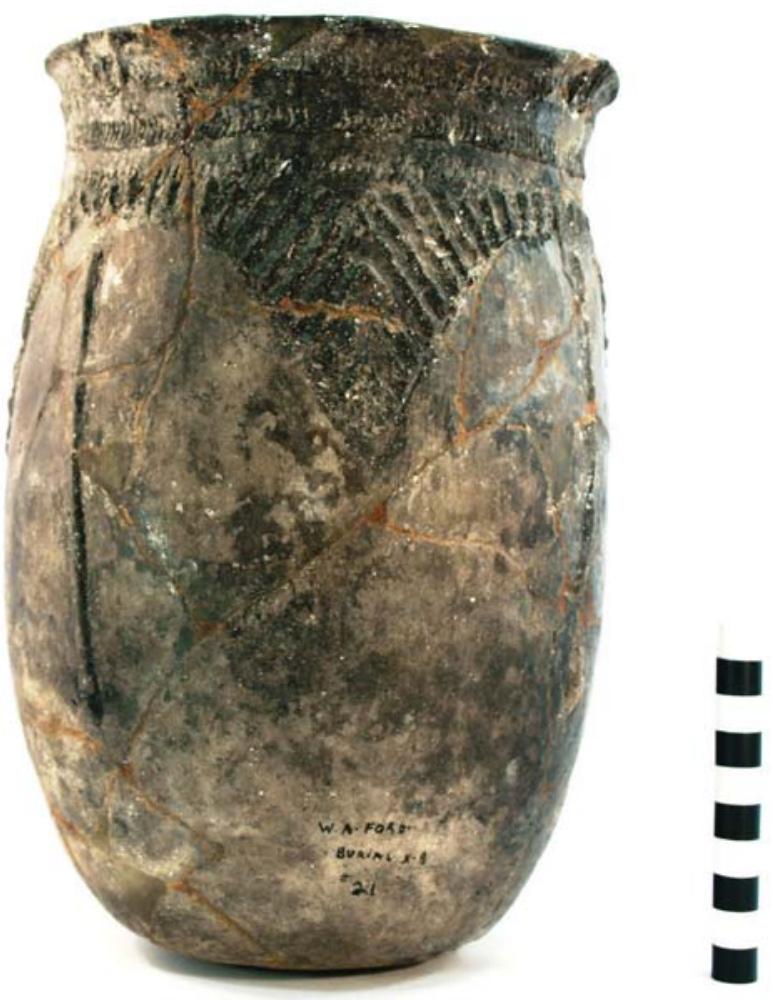

Figure 27. Emory Punctated-Incised jar from Burial X-8 at the W. A. Ford site.

\section{ESTIMATED VOLUME (IN LITERS): 5.8}

DECORATION (INCLUDING MOTIF AND ELEMENTS WHEN APPARENT): The rim is decorated with three horizontal rows of fingernail punctates. The vessel body has four repeating sets of appliqued ridge triangles (and connecting curvilinear appliqued ridges) filled with diagonal opposed appliqued ridges (Figure 27). Between each of the large appliqued triangles are four vertical appliqued ridges.

PIGMENT USE AND LOCATION ON VESSEL: none

TYPE AND VARIETY (IF KNOWN): Emory Punctated-Incised 
SITE NAME OR SITE NUMBER: W. A. Ford (41TT2)

VESSEL NO.: 22, Burial X-8

VESSEL FORM: Carinated bowl, hubcap style

NON-PLASTICS AND PASTE: shell

RIM AND LIP FORM: Inverted rim and rounded lip

CORE COLOR: B (fired and cooled in a reducing environment)

INTERIOR SURFACE COLOR: grayish-brown

EXTERIOR SURFACE COLOR: dark grayish-brown

WALL THICKNESS (IN MM): rim, 4.0 mm

INTERIOR SURFACE

TREATMENT: smoothed

EXTERIOR SURFACE

TREATMENT: burnished

HEIGHT (IN CM): 6.4

ORIFICE DIAMETER (IN CM): 11.8

DIAMETER AT BOTTOM OF RIM

OR NECK (IN CM): 14.0

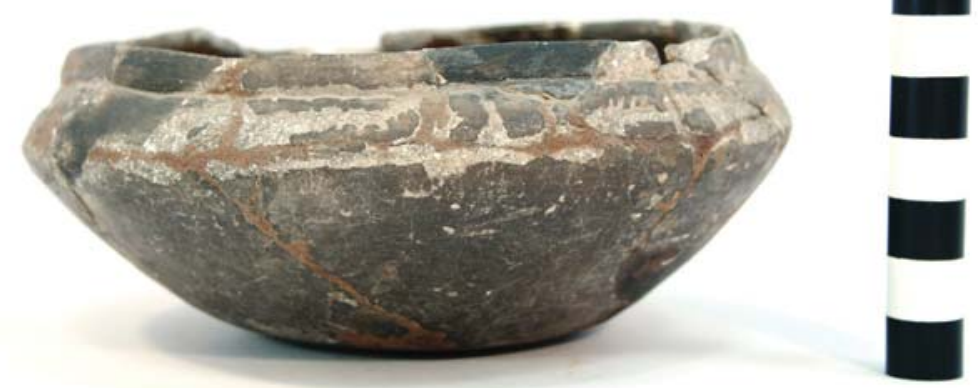

Figure 28. Simms Engraved, var. Darco carinated bowl from Burial $\mathrm{X}-8$ at the W. A. Ford site.

BASE DIAMETER (IN CM) AND SHAPE OF BASE: 6.4; circular and rounded

ESTIMATED VOLUME (IN LITERS): 0.45

DECORATION (INCLUDING MOTIF AND ELEMENTS WHEN APPARENT): The rim panel has a series of four discontinuous diagonal engraved lines with linear tick marks either pointing upward towards the rim or downward towards the vessel carination (Figure 28).

\section{PIGMENT USE AND LOCATION ON VESSEL: none}

TYPE AND VARIETY (IF KNOWN): Simms Engraved, var. Darco. Darco Engraved was initially identified by Jones (1968:161-163) from historic Caddo Kinsloe phase sites in the Sabine Rive basin. Jones (1968:163) noted its similarity in paste and decoration to Simms Engraved vessels, as Darco Engraved vessels were tempered with grog as well as shell, and were carinated bowls with a small rim panel (to which the decorative motif was confined) and an outflaring rim. Jones (1968:162) described the design as consisting of "from four to seven panels formed by "ticked" vertical, diagonal, and horizontal lines extending from a plain horizontal base line where the rim and shoulder meet." More recently, Perttula et al. (2010) have reclassified Darco Engraved as Simms Engraved, var. Darco. Vessels of this type and variety occasionally have notched lips but always have discontinuous engraved elements with downward-pointing tick marks. Most have four repeating sets of curvilinear to semi-circular ticked engraved lines. 
SITE NAME OR SITE NUMBER: W. A. Ford (41TT2)

VESSEL NO.: 23, Burial X-8

VESSEL FORM: Carinated bowl

NON-PLASTICS AND PASTE: grog

RIM AND LIP FORM: Direct rim and rounded, exterior folded lip

CORE COLOR: G (fired in a reducing environment and cooled in the open air)

INTERIOR SURFACE COLOR: grayish-brown; organic residue on the rim

EXTERIOR SURFACE COLOR: brown;

fire clouds on the rim, body, and base;

organic residue on the rim

WALL THICKNESS (IN MM):

rim, $6.4 \mathrm{~mm}$

INTERIOR SURFACE

TREATMENT: smoothed on the rim

EXTERIOR SURFACE

TREATMENT: burnished

HEIGHT (IN CM): 12.2

ORIFICE DIAMETER (IN

CM): 21.2

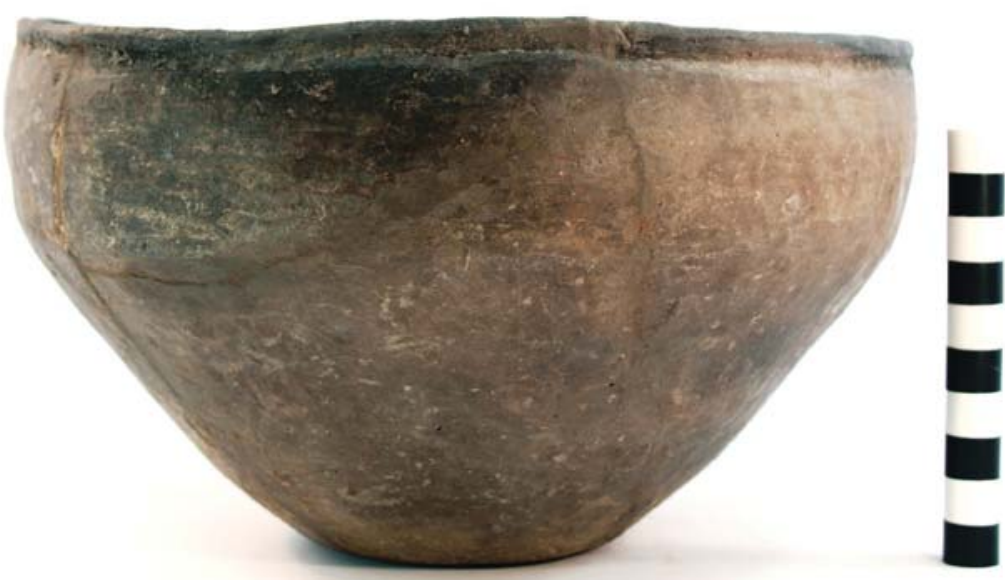

Figure 29. Plain carinated bowl from Burial $\mathrm{X}-8$ at the W. A. Ford site.

DIAMETER AT BOTTOM OF

RIM OR NECK (IN CM): 21.3

BASE DIAMETER (IN CM) AND SHAPE OF BASE: 7.0; circular and flat

ESTIMATED VOLUME (IN LITERS): 1.5

DECORATION (INCLUDING MOTIF AND ELEMENTS WHEN APPARENT): Plain (Figure 29)

PIGMENT USE AND LOCATION ON VESSEL: none

TYPE AND VARIETY (IF KNOWN): Unidentified plain ware 
SITE NAME OR SITE NUMBER: W. A. Ford (41TT2)

VESSEL NO.: 24, Burial X-8

VESSEL FORM: Jar

NON-PLASTICS AND PASTE: grog

RIM AND LIP FORM: Everted rim and rounded lip

CORE COLOR: $\mathrm{F}$ (fired in a reducing environment and cooled in the open air)

INTERIOR SURFACE COLOR: dark yellowish-brown; fire clouds on the rim and body

EXTERIOR SURFACE COLOR: brown to dark yellowish-brown; fire clouds on the rim and body; organic residue on the body

WALL THICKNESS (IN MM):

rim, $6.5 \mathrm{~mm}$

INTERIOR SURFACE

TREATMENT: smoothed

EXTERIOR SURFACE

TREATMENT: smoothed on the body

HEIGHT (IN CM): 11.3

ORIFICE DIAMETER (IN

CM): 13.4

DIAMETER AT BOTTOM OF

RIM OR NECK (IN CM): 13.0

BASE DIAMETER (IN CM) AND SHAPE OF BASE: 6.4; circular and flat

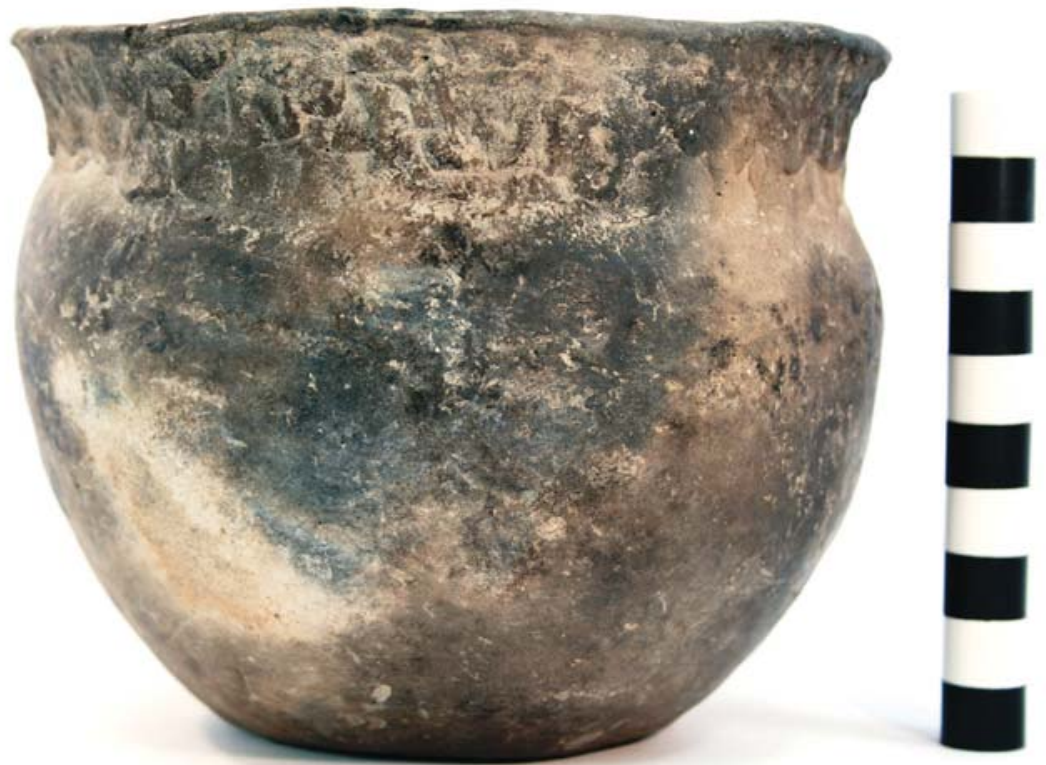

Figure 30. La Rue Neck Banded jar from Burial X-8 at the W. A. Ford site.

ESTIMATED VOLUME

(IN LITERS): 0.91

DECORATION (INCLUDING MOTIF AND ELEMENTS WHEN APPARENT): There are four horizontal rows of neck bands on the vessel rim (Figure 30).

PIGMENT USE AND LOCATION ON VESSEL: none

TYPE AND VARIETY (IF KNOWN): La Rue Neck Banded 
SITE NAME OR SITE NUMBER: W. A. Ford (41TT2)

VESSEL NO.: 39, Burial X-9

VESSEL FORM: Carinated bowl

NON-PLASTICS AND PASTE: grog

RIM AND LIP FORM: Direct rim and rounded, exterior folded lip

CORE COLOR: $\mathrm{G}$ (fired in a reducing environment and cooled in the open air)

INTERIOR SURFACE COLOR: grayish-brown

EXTERIOR SURFACE COLOR: dark yellowish-brown; fire clouds on the rim, body, and base

WALL THICKNESS (IN

MM): rim, $6.6 \mathrm{~mm}$

INTERIOR SURFACE

TREATMENT: smoothed

EXTERIOR SURFACE

TREATMENT: burnished

HEIGHT (IN CM): 14.6

ORIFICE DIAMETER (IN

CM): 29.1

DIAMETER AT BOTTOM

OF RIM OR NECK (IN

CM): 28.9

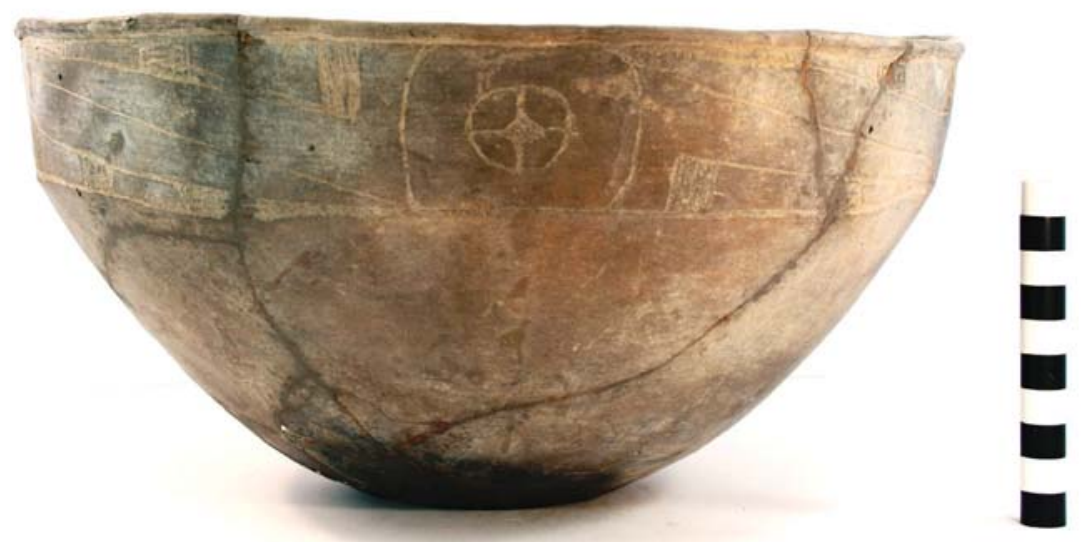

Figure 31. Ripley Engraved, var. Galt carinated bowl from Burial X-9 at the W. A. Ford site.

BASE DIAMETER (IN CM) AND SHAPE OF BASE: 8.2; circular and flat

ESTIMATED VOLUME (IN LITERS): 3.8

DECORATION (INCLUDING MOTIF AND ELEMENTS WHEN APPARENT): The rim panel has an engraved scroll and circle motif repeated four times around the vessel (Figure 31). The circle elements have a central inner circle with an inner excised diamond element and four radiating engraved lines. The upper and lower scroll fill zones have excised rectangle and triangle elements (Figure 31).

PIGMENT USE AND LOCATION ON VESSEL: none

TYPE AND VARIETY (IF KNOWN): Ripley Engraved, var. Galt 
SITE NAME OR SITE NUMBER: W. A. Ford (41TT2)

VESSEL NO.: 40, Burial X-9

VESSEL FORM: Bottle

NON-PLASTICS AND PASTE: grog

RIM AND LIP FORM: Everted rim and rounded lip

CORE COLOR: B (fired and cooled in a reducing environment)

INTERIOR SURFACE COLOR: very dark grayish-brown

EXTERIOR SURFACE COLOR: very dark grayish-brown; fire clouds on the body

WALL THICKNESS (IN MM): neck, $6.3 \mathrm{~mm}$

INTERIOR SURFACE TREATMENT: none

EXTERIOR SURFACE TREATMENT:

burnished

HEIGHT (IN CM): 12.2

ORIFICE DIAMETER (IN CM): 2.9

DIAMETER AT BOTTOM OF RIM OR NECK

(IN CM): 3.9; maximum body diameter of 6.8 $\mathrm{cm}$

BASE DIAMETER (IN CM) AND SHAPE OF

BASE: 5.3; circular and flat

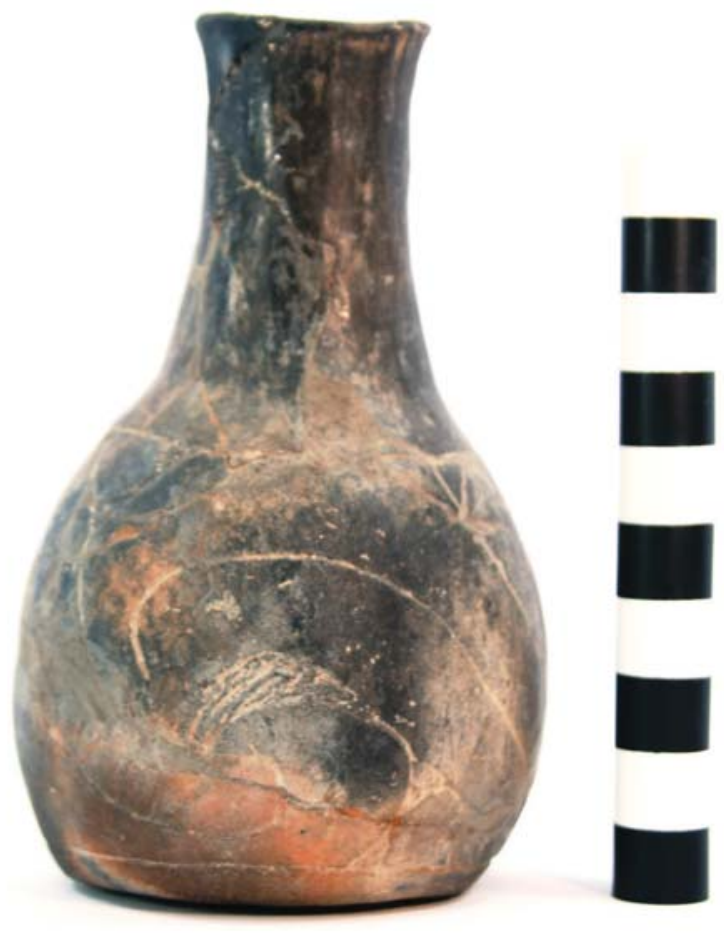

Figure 32. Wilder Engraved bottle from Burial X-9 at the W. A. Ford site.

ESTIMATED VOLUME (IN LITERS): 0.26

DECORATION (INCLUDING MOTIF AND ELEMENTS WHEN APPARENT): The vessel body has a curvilinear and spiral engraved motif repeated three times around the vessel. The vessel body panel is defined by upper and lower horizontal engraved lines. The engraved motif consists of upper and lower engraved spirals that meet either at an excised curvilinear zone or a vertical and curvilinear engraved line that begins at the apex of engraved pendant triangles (Figure 32). The spirals and lines begin from upper and lower engraved pendant triangles with excised or hatched corners.

PIGMENT USE AND LOCATION ON VESSEL: none

TYPE AND VARIETY (IF KNOWN): Wilder Engraved 
SITE NAME OR SITE NUMBER: W. A. Ford (41TT2)

VESSEL NO.: 41, Burial X-9

VESSEL FORM: Compound bowl

NON-PLASTICS AND PASTE: shell

RIM AND LIP FORM: everted rim and rounded lip

CORE COLOR: $\mathrm{F}$ (fired in a reducing

environment and cooled in the open air)

INTERIOR SURFACE COLOR: red

EXTERIOR SURFACE COLOR: red

WALL THICKNESS (IN MM): rim, $4.6 \mathrm{~mm}$

INTERIOR SURFACE TREATMENT:

smoothed

EXTERIOR SURFACE TREATMENT:

burnished

HEIGHT (IN CM): 16.8

ORIFICE DIAMETER (IN CM): 14.2

DIAMETER AT BOTTOM OF RIM OR

NECK (IN CM): 13.5

BASE DIAMETER (IN CM) AND SHAPE

OF BASE: 7.0; circular and flat

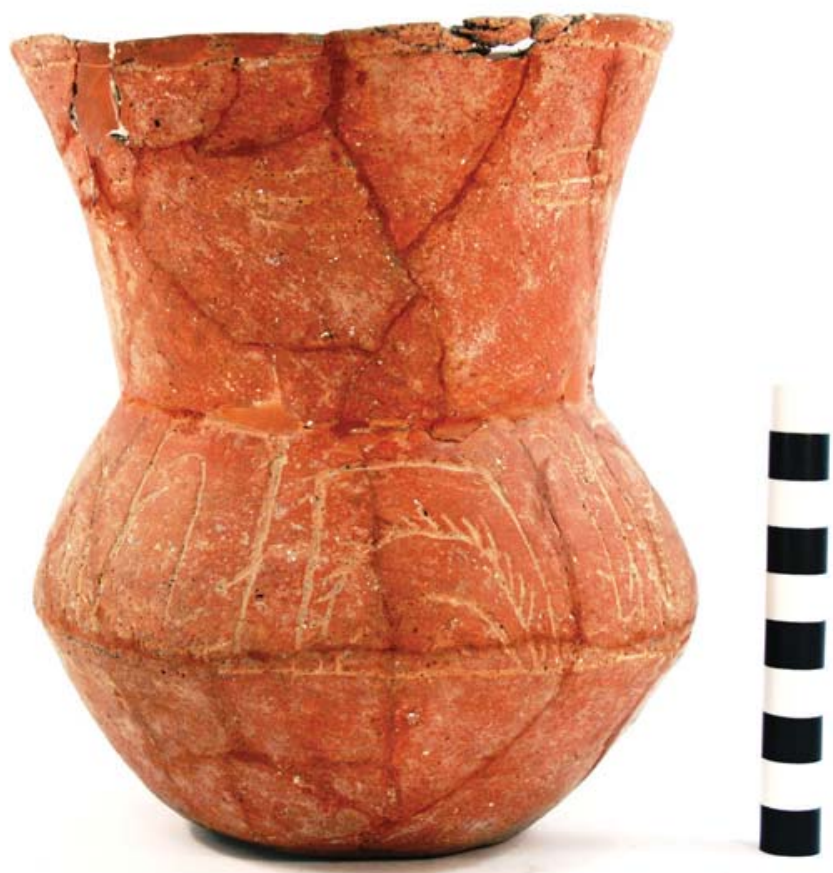

Figure 33. Avery Engraved compound bowl from Burial X-9 at the W. A. Ford site.

ESTIMATED VOLUME (IN LITERS): 1.9

DECORATION (INCLUDING MOTIF AND ELEMENTS WHEN APPARENT): Interior and exterior red-slipped vessel surfaces. The upper rim panel has six ovoid engraved elements with a single horizontal line bisecting the ovoid (Figure 33). The lower panel has two different motifs repeated four times: (1) rectilinear panels with a single curvilinear engraved line and a small hooked line pendant from the panel; and (2) rectilinear panels filled with two semi-circular engraved lines; the outermost engraved line has short linear engraved marks (Figure 33).

PIGMENT USE AND LOCATION ON VESSEL: none

TYPE AND VARIETY (IF KNOWN): Avery Engraved 
SITE NAME OR SITE NUMBER: W. A. Ford (41TT2)

VESSEL NO.: 42, Burial X-9

VESSEL FORM: Deep bowl with short rim (see Suhm and Jelks 1962:Plate 71e)

NON-PLASTICS AND PASTE: shell

RIM AND LIP FORM: Inverted-direct rim and rounded lip

CORE COLOR: A (fired and cooled in an oxidizing environment)

INTERIOR SURFACE COLOR: red

EXTERIOR SURFACE COLOR: red; fire clouds on the rim

WALL THICKNESS (IN MM):

rim, $5.3 \mathrm{~mm}$

INTERIOR SURFACE

TREATMENT: smoothed

EXTERIOR SURFACE

TREATMENT: burnished

HEIGHT (IN CM): 20.3

ORIFICE DIAMETER

(IN CM): 16.7

DIAMETER AT BOTTOM OF

RIM OR NECK (IN CM): 20.2

BASE DIAMETER (IN CM)

AND SHAPE OF BASE: 10.8;

circular and flat

ESTIMATED VOLUME

(IN LITERS): 2.7



Figure 34. cf. Simms Plain deep bowl from Burial X-9 at the W. A. Ford site.

DECORATION (INCLUDING MOTIF AND ELEMENTS WHEN APPARENT): Interior/exterior redslipped, except on the base (Figure 34)

PIGMENT USE AND LOCATION ON VESSEL: none

TYPE AND VARIETY (IF KNOWN): cf. Simms Plain 
SITE NAME OR SITE NUMBER: W. A. Ford (41TT2)

VESSEL NO.: 43, Burial X-9

VESSEL FORM: Carinated bowl

NON-PLASTICS AND PASTE: grog

RIM AND LIP FORM: Direct rim and rounded lip

CORE COLOR: $\mathrm{F}$ (fired in a reducing environment and cooled in the open air)

INTERIOR SURFACE COLOR: red

EXTERIOR SURFACE COLOR: red; fire cloud on the base

WALL THICKNESS (IN MM): rim, 7.4 mm

INTERIOR SURFACE TREATMENT: smoothed

EXTERIOR SURFACE

TREATMENT: burnished

HEIGHT (IN CM): 16.5

ORIFICE DIAMETER (IN

CM): 28.4

DIAMETER AT BOTTOM

OF RIM OR NECK (IN

CM): 28.2

BASE DIAMETER (IN

CM) AND SHAPE OF

BASE: 9.5 ; circular and flat

ESTIMATED VOLUME

(IN LITERS): 4.3

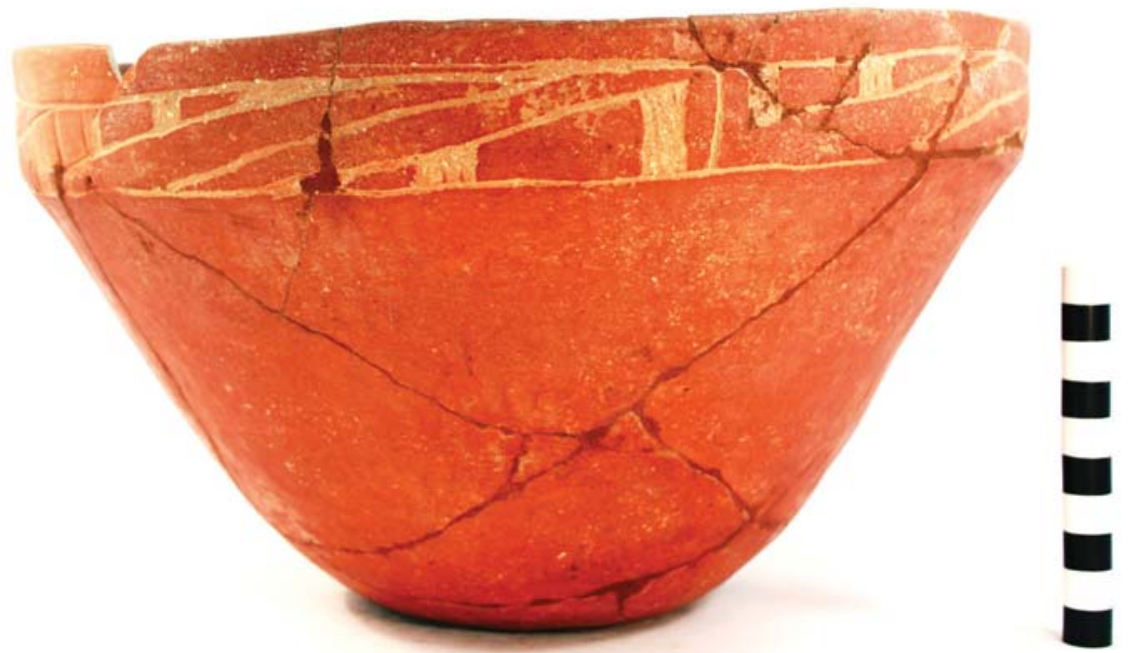

Figure 35. Ripley Engraved, var. Carpenter carinated bowl from Burial X-9 at the W. A. Ford site.

DECORATION (INCLUDING MOTIF AND ELEMENTS WHEN APPARENT): The vessel has a red slip on both interior and exterior vessel surfaces. The rim panel has an engraved continuous scroll motif repeated five times around the vessel (Figure 35). The upper and lower scroll fill zones have excised rectangles and triangular elements.

PIGMENT USE AND LOCATION ON VESSEL: none

TYPE AND VARIETY (IF KNOWN): Ripley Engraved, var. Carpenter 
SITE NAME OR SITE NUMBER: W. A. Ford (41TT2)

VESSEL NO.: 45, Burial X-9

VESSEL FORM: Carinated bowl

NON-PLASTICS AND PASTE: grog

RIM AND LIP FORM: Direct rim and rounded lip

CORE COLOR: B (fired and cooled in a reducing environment)

INTERIOR SURFACE COLOR: dark grayish-brown

EXTERIOR SURFACE COLOR: dark grayish-brown

WALL THICKNESS

(IN MM): rim, $6.7 \mathrm{~mm}$

INTERIOR SURFACE TREATMENT:

smoothed

EXTERIOR SURFACE TREATMENT:

smoothed

HEIGHT (IN CM): 7.6

ORIFICE DIAMETER

(IN CM): 17.2

DIAMETER AT

BOTTOM OF RIM OR

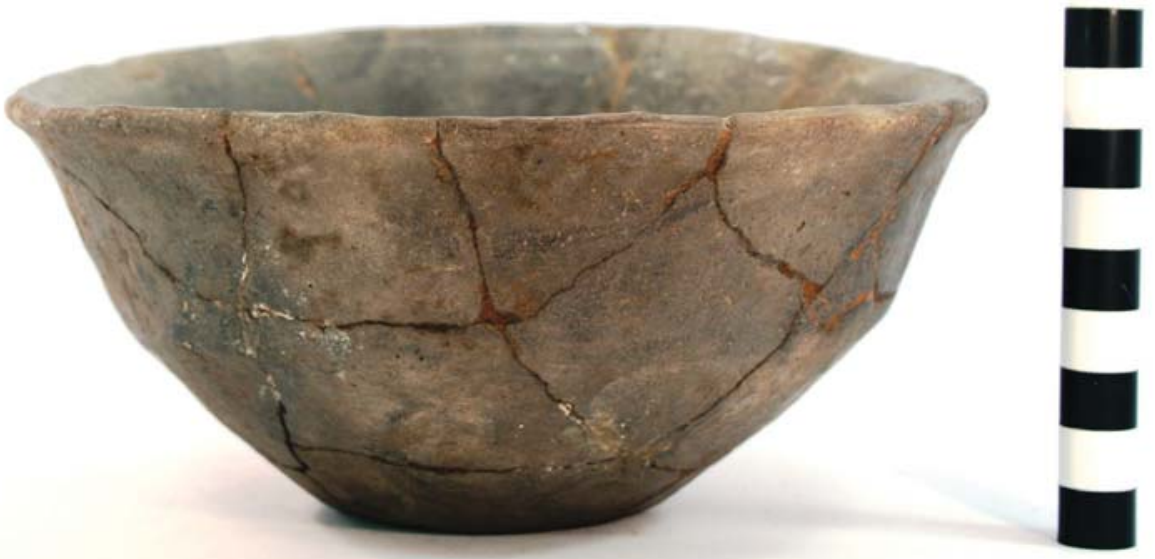

Figure 36. Plain carinated bowl from Burial X-9 at the W. A. Ford site.

NECK (IN CM): 16.8

BASE DIAMETER (IN CM) AND SHAPE OF BASE: 5.2; circular and flat

ESTIMATED VOLUME (IN LITERS): 0.79

DECORATION (INCLUDING MOTIF AND ELEMENTS WHEN APPARENT): Plain (Figure 36)

PIGMENT USE AND LOCATION ON VESSEL: none

TYPE AND VARIETY (IF KNOWN): Unidentified plain ware 
SITE NAME OR SITE NUMBER: W. A. Ford (41TT2)

VESSEL NO.: 46, Burial X-9

VESSEL FORM: Jar

NON-PLASTICS AND PASTE: grog

RIM AND LIP FORM: Everted rim and rounded lip

CORE COLOR: $\mathrm{F}$ (fired in a reducing environment and cooled in the open air)

INTERIOR SURFACE COLOR: yellowish-brown; fire clouds on the rim, body, and base

EXTERIOR SURFACE COLOR: yellowishbrown; fire clouds on the rim, body, and base

WALL THICKNESS (IN MM): rim, 6.0 mm

INTERIOR SURFACE TREATMENT: smoothed on the rim

EXTERIOR SURFACE TREATMENT: none

HEIGHT (IN CM): 14.6

ORIFICE DIAMETER (IN CM): 13.2

DIAMETER AT BOTTOM OF RIM OR NECK (IN CM): 10.0

BASE DIAMETER (IN CM) AND SHAPE OF

BASE: 7.6; circular and flat

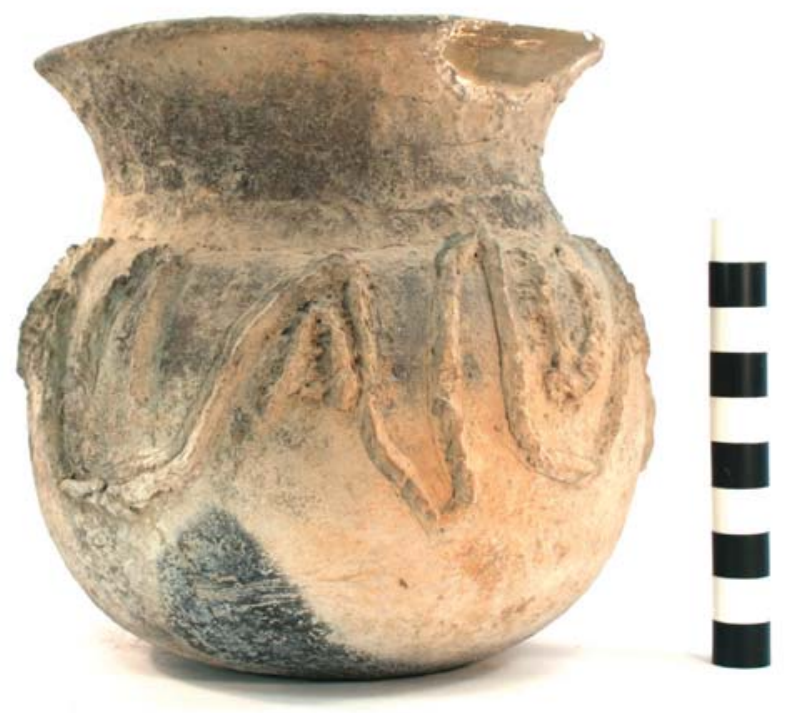

Figure 37. La Rue Neck Banded jar from Burial X-9 at the W. A. Ford site.

ESTIMATED VOLUME (IN LITERS): 1.2

DECORATION (INCLUDING MOTIF AND ELEMENTS WHEN APPARENT): The rim of the vessel has four horizontal neck banded rows (Figure 37). The vessel body has an appliqued ridge meandering scroll motif, with two small upturned curvilinear appliqued ridges below the base of the rim, and five small downturned curvilinear appliqued ridges; these appliqued ridge elements also have a tool punctated-filled zone and a row of tool punctates along the outer edge of the ridges (Figure 37).

PIGMENT USE AND LOCATION ON VESSEL: none

TYPE AND VARIETY (IF KNOWN): La Rue Neck Banded 
SITE NAME OR SITE NUMBER: W. A. Ford (41TT2)

VESSEL NO.: 47, Burial X-9

VESSEL FORM: Jar

NON-PLASTICS AND PASTE: grog

RIM AND LIP FORM: Everted rim and rounded lip

CORE COLOR: B (fired and cooled in a reducing environment)

INTERIOR SURFACE COLOR: very dark grayish-brown; organic residue on the rim and body

EXTERIOR SURFACE COLOR: very dark grayish-brown; fire clouds on the body and base

WALL THICKNESS (IN MM): rim, $5.3 \mathrm{~mm}$

INTERIOR SURFACE TREATMENT: smoothed on the rim

EXTERIOR SURFACE TREATMENT: smoothed on the body

HEIGHT (IN CM): 18.9

ORIFICE DIAMETER (IN CM): 14.8

DIAMETER AT BOTTOM OF RIM OR NECK (IN CM): 13.8

BASE DIAMETER (IN CM) AND SHAPE OF BASE: 6.4; circular and flat

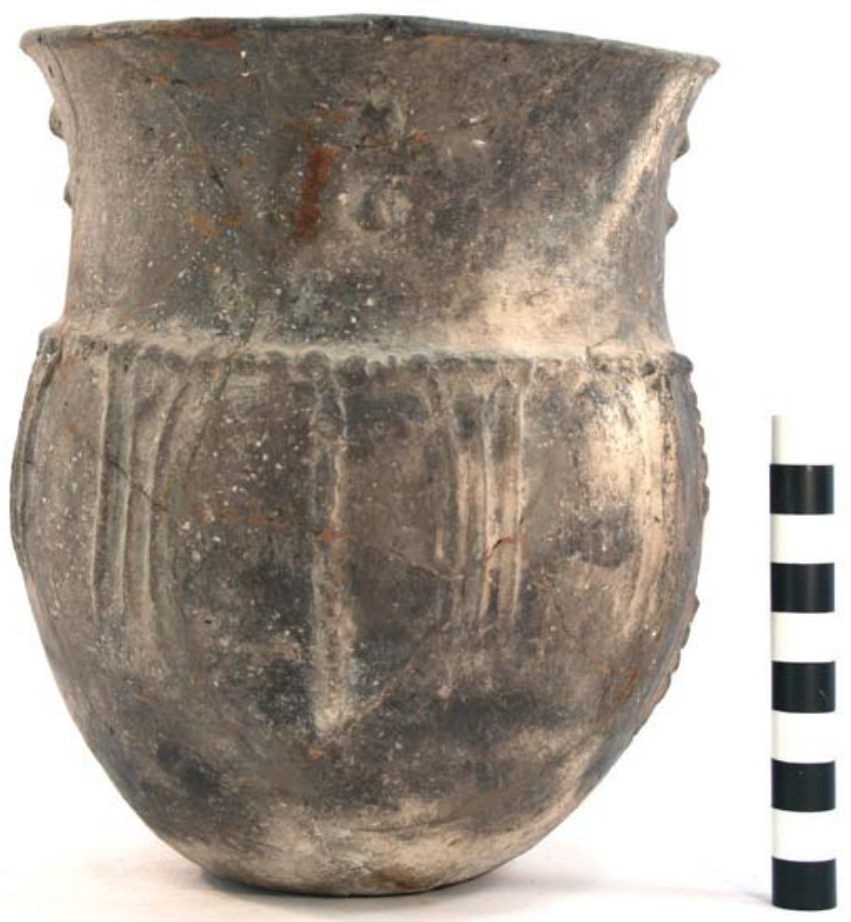

Figure 38. Unidentified appliqued utility ware jar from Burial X-9 at the W. A. Ford site.

ESTIMATED VOLUME (IN LITERS): 2.5

DECORATION (INCLUDING MOTIF AND ELEMENTS WHEN APPARENT): The rim of the vessel has four sets of two appliqued nodes, one above the other (Figure 38). There is also a horizontal appliqued fillet at the rim-body juncture, and a series of four vertical appliqued fillets on the vessel body between two sets of three vertical appliqued ridges (Figure 38).

PIGMENT USE AND LOCATION ON VESSEL: none

TYPE AND VARIETY (IF KNOWN): Unidentified utility ware 
SITE NAME OR SITE NUMBER: W. A. Ford (41TT2)

VESSEL NO.: 48, Burial X-9

VESSEL FORM: Carinated bowl

NON-PLASTICS AND PASTE: grog

RIM AND LIP FORM: Direct rim and rounded, exterior folded lip

CORE COLOR: F (fired in a reducing environment and cooled in the open air)

INTERIOR SURFACE COLOR: brown to grayish-brown

EXTERIOR SURFACE

COLOR: brown; fire clouds on the rim and body

WALL THICKNESS (IN

MM): rim, $7.0 \mathrm{~mm}$

INTERIOR SURFACE

TREATMENT: burnished on the rim

EXTERIOR SURFACE

TREATMENT: burnished

HEIGHT (IN CM): 18.6

ORIFICE DIAMETER (IN

$\mathrm{CM}): 28.4$

DIAMETER AT BOTTOM OF

RIM OR NECK (IN CM): 28.4

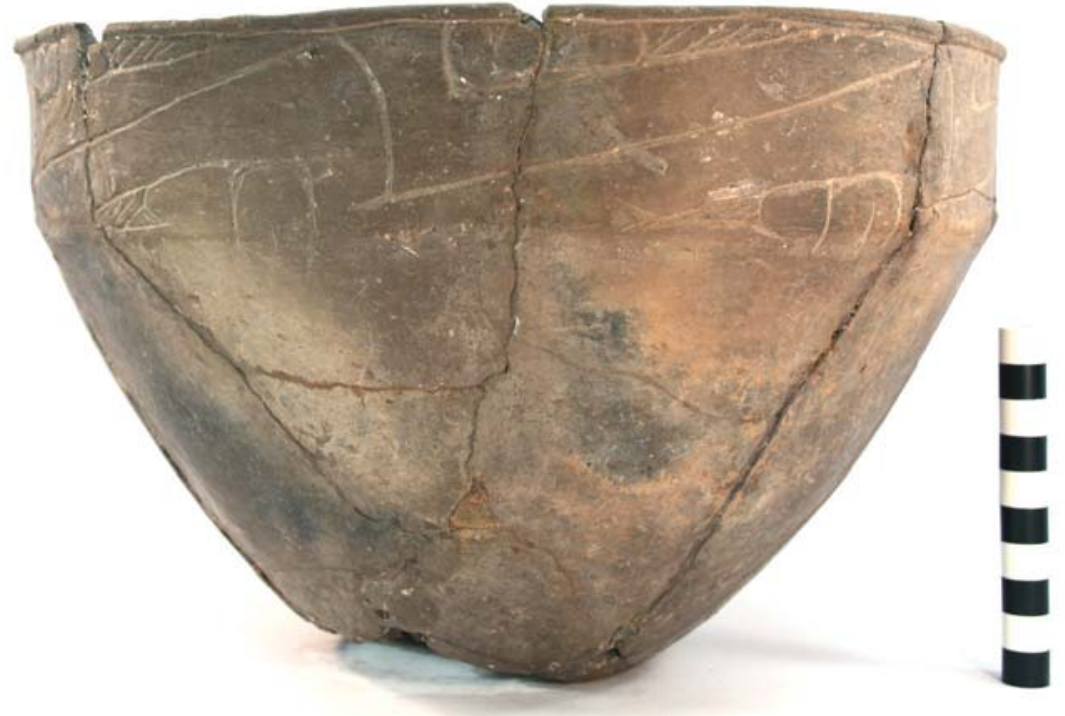

Figure 39. Ripley Engraved, var. Carpenter carinated bowl from Burial X-9 at the W. A. Ford site.

BASE DIAMETER (IN CM) AND SHAPE OF BASE: 8.9; circular and flat

ESTIMATED VOLUME (IN LITERS): 4.7

DECORATION (INCLUDING MOTIF AND ELEMENTS WHEN APPARENT): The rim panel has an engraved continuous scroll motif repeated seven times around the vessel (Figure 39). The upper and lower scroll fill zones have hatched triangular elements and negative ovals with excised corners. These ovals have within them either a single excised pendant triangle or short excised lines that partially bisect the ovals (Figure 39).

PIGMENT USE AND LOCATION ON VESSEL: none

TYPE AND VARIETY (IF KNOWN): Ripley Engraved, var. Carpenter 
SITE NAME OR SITE NUMBER: W. A. Ford (41TT2)

VESSEL NO.: 53, Burial X-11

VESSEL FORM: Carinated bowl

NON-PLASTICS AND PASTE: grog and bone

RIM AND LIP FORM: Inverted rim and rounded, exterior folded lip

CORE COLOR: B (fired and cooled in a reducing environment)

INTERIOR SURFACE COLOR: grayish-brown; organic residue on the rim

EXTERIOR SURFACE COLOR: dark grayish-brown; fire clouds on the rim and body; organic residue on the body

WALL THICKNESS (IN MM): rim, 5.6 mm

INTERIOR SURFACE

TREATMENT: none

EXTERIOR SURFACE

TREATMENT: smoothed

HEIGHT (IN CM): 12.4

ORIFICE DIAMETER (IN

CM): 22.9

DIAMETER AT BOTTOM

OF RIM OR NECK (IN

$\mathrm{CM}): 23.1$

BASE DIAMETER (IN

CM) AND SHAPE OF

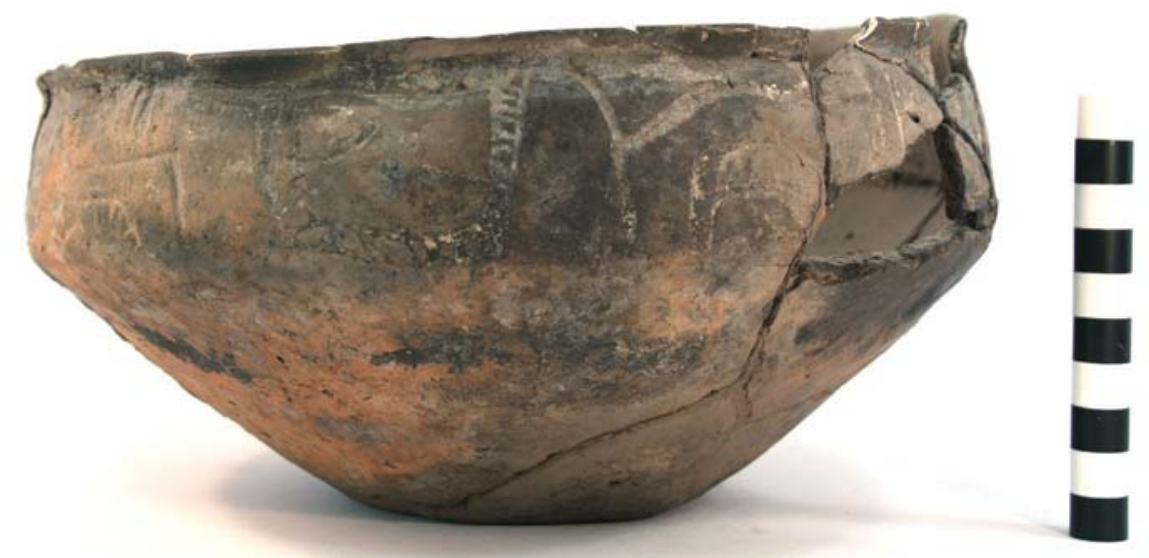

Figure 40. Unidentified engraved carinated bowl from Burial X-11 at the W. A. Ford site.

BASE: 8.2 ; circular and concave

ESTIMATED VOLUME (IN LITERS): 1.7

DECORATION (INCLUDING MOTIF AND ELEMENTS WHEN APPARENT): The rim panel has a series of engraved elements, including hatched curvilinear and rectilinear zones, curvilinear engraved lines, and semi-circles (Figure 40).

PIGMENT USE AND LOCATION ON VESSEL: none

TYPE AND VARIETY (IF KNOWN): Unidentified fine ware 
SITE NAME OR SITE NUMBER: W. A. Ford (41TT2)

VESSEL NO.: 54, Burial X-11

VESSEL FORM: Carinated bowl

NON-PLASTICS AND PASTE: grog

RIM AND LIP FORM: Direct rim and rounded, exterior folded lip

CORE COLOR: $\mathrm{F}$ (fired in a reducing environment and cooled in the open air)

INTERIOR SURFACE COLOR: dark yellowish-brown; fire clouds on the rim and body

EXTERIOR SURFACE COLOR:

dark yellowish-brown; fire clouds

on the rim, body, and base

WALL THICKNESS (IN MM):

rim, $6.6 \mathrm{~mm}$

INTERIOR SURFACE

TREATMENT: smoothed

on the rim

EXTERIOR SURFACE

TREATMENT: burnished

HEIGHT (IN CM): 15.8

ORIFICE DIAMETER

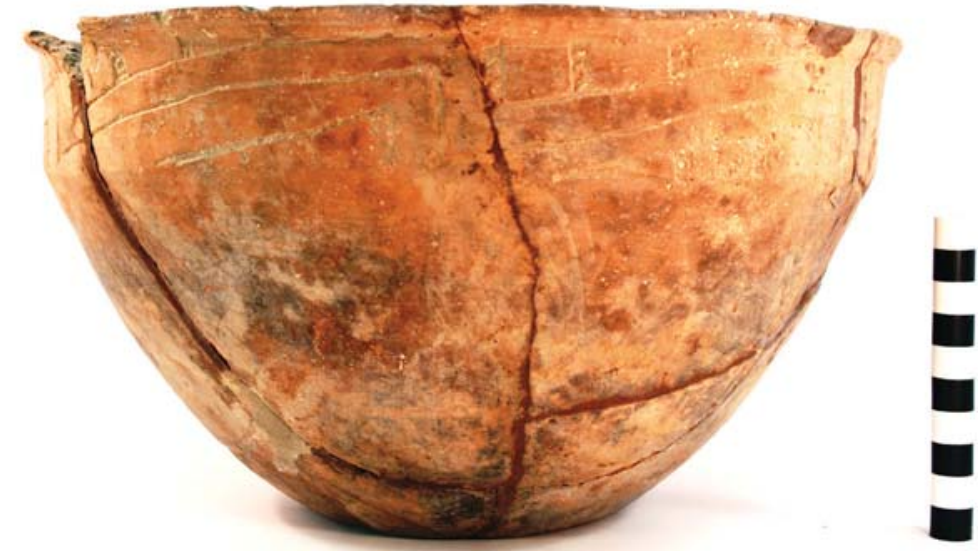

Figure 41. Ripley Engraved, var. Carpenter carinated bowl from Burial X-11 at the W. A. Ford site (41TT2).

(IN CM): 28.0

DIAMETER AT BOTTOM OF RIM OR NECK (IN CM): 27.7

BASE DIAMETER (IN CM) AND SHAPE OF BASE: 10.2; circular and flat

ESTIMATED VOLUME (IN LITERS): 4.0

DECORATION (INCLUDING MOTIF AND ELEMENTS WHEN APPARENT): The rim panel has an engraved continuous scroll motif repeated six times around the vessel (Figure 41). The upper and lower scroll fill zones have vertical hatched zones, excised ovals, and curvilinear excised elements with a triangular tick mark at their ends.

PIGMENT USE AND LOCATION ON VESSEL: none

TYPE AND VARIETY (IF KNOWN): Ripley Engraved, var. Carpenter 
SITE NAME OR SITE NUMBER: W. A. Ford (41TT2)

VESSEL NO.: 55, Burial X-11

VESSEL FORM: Compound bowl

NON-PLASTICS AND PASTE: grog

RIM AND LIP FORM: Everted rim and rounded lip

CORE COLOR: G (fired in a reducing environment and cooled in the open air)

INTERIOR SURFACE COLOR: grayish-brown; fire clouds on the rim

EXTERIOR SURFACE COLOR: yellowish-brown; fire clouds on the rim, body, and base

WALL THICKNESS (IN MM): rim, $7.7 \mathrm{~mm}$

INTERIOR SURFACE

TREATMENT: burnished on the upper panel and smoothed on the remainder of the vessel interior

EXTERIOR SURFACE

TREATMENT: burnished

HEIGHT (IN CM): 29.0

ORIFICE DIAMETER (IN CM): 38.0

DIAMETER AT BOTTOM OF

RIM OR NECK (IN CM): 34.0

BASE DIAMETER (IN CM)

AND SHAPE OF BASE: 10.2;

circular and concave

ESTIMATED VOLUME (IN

LITERS): 8.8



Figure 42. Ripley Engraved, var. Carpenter compound bowl from Burial X-11 at the W. A. Ford site (41TT2).

DECORATION (INCLUDING MOTIF AND ELEMENTS WHEN APPARENT): The upper panel of the vessel is plain, and there is a single horizontal engraved line at the juncture of the upper and lower rim panels (Figure 42). The lower rim panel has an engraved continuous scroll motif repeated seven times around the vessel; the continuous scroll line has distinctive curvilinear elements. The upper and lower scroll fill zones are marked by curvilinear lines at one end of the scroll fill zone, with excised negative ovals and "heartshaped" elements at the end of the scroll fill zone nearest the curvilinear scroll line (Figure 42).

PIGMENT USE AND LOCATION ON VESSEL: none

TYPE AND VARIETY (IF KNOWN): Ripley Engraved, var. Carpenter 
SITE NAME OR SITE NUMBER: W. A. Ford (41TT2)

VESSEL NO.: 56, Burial X-11

VESSEL FORM: Carinated bowl

NON-PLASTICS AND PASTE: grog

RIM AND LIP FORM: Direct rim and a rounded, exterior folded lip

CORE COLOR: $\mathrm{G}$ (fired in a reducing environment and cooled in the open air)

INTERIOR SURFACE COLOR: grayish-brown

EXTERIOR SURFACE COLOR: light reddish-brown; fire clouds on the rim, body, and vessel base

WALL THICKNESS (IN

MM): rim, $7.7 \mathrm{~mm}$

INTERIOR SURFACE

TREATMENT: smoothed on the rim

EXTERIOR SURFACE

TREATMENT: burnished

HEIGHT (IN CM): 15.9

ORIFICE DIAMETER

(IN CM): 24.2

DIAMETER AT

BOTTOM OF RIM OR

NECK (IN CM): 24.4

BASE DIAMETER (IN

CM) AND SHAPE OF

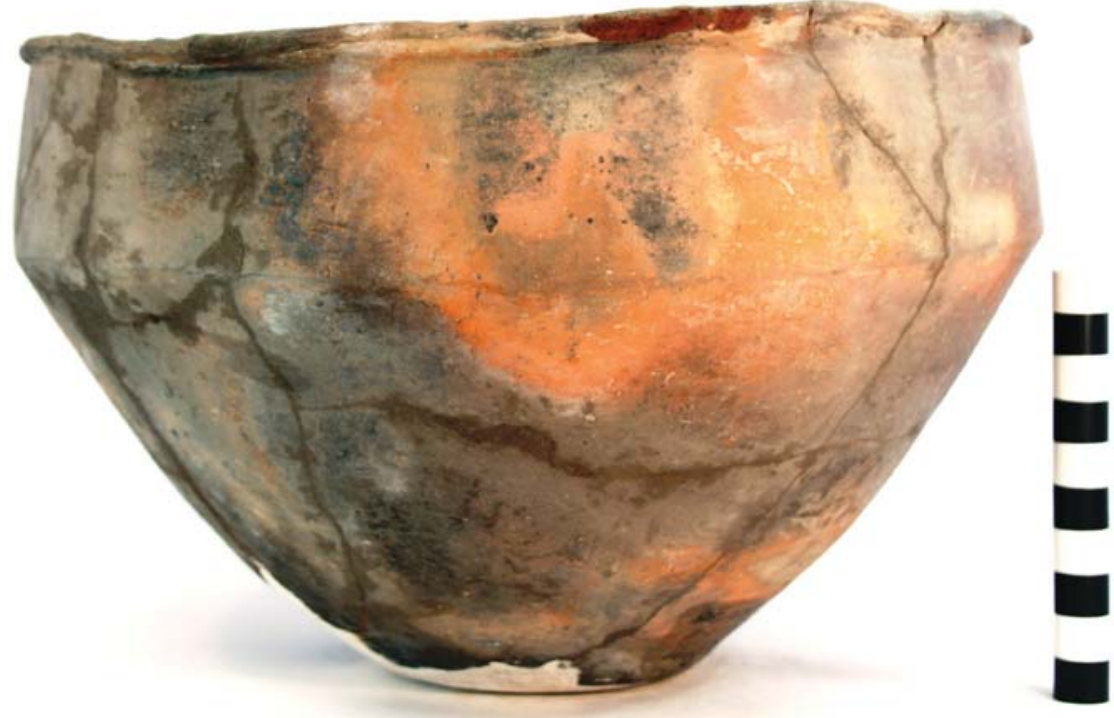

Figure 43. Plain carinated bowl from Burial X-11 at the W. A. Ford site (41TT2).

BASE: 7.7 ; circular and flat

ESTIMATED VOLUME (IN LITERS): 3.5

DECORATION (INCLUDING MOTIF AND ELEMENTS WHEN APPARENT): Plain (Figure 43)

PIGMENT USE AND LOCATION ON VESSEL: none

TYPE AND VARIETY (IF KNOWN): Unidentified plain ware 
SITE NAME OR SITE NUMBER: W. A. Ford (41TT2)

VESSEL NO.: 57, Burial X-11

VESSEL FORM: Carinated bowl

NON-PLASTICS AND PASTE: grog and bone

RIM AND LIP FORM: Direct rim and rounded, exterior folded lip

CORE COLOR: $\mathrm{G}$ (fired in a reducing environment and cooled in the open air)

INTERIOR SURFACE COLOR: grayish-brown

EXTERIOR SURFACE COLOR: yellowish-brown; fire clouds on the rim, body, and base

WALL THICKNESS (IN MM): rim, $6.5 \mathrm{~mm}$

INTERIOR SURFACE

TREATMENT: smoothed on the rim

EXTERIOR SURFACE

TREATMENT: smoothed

HEIGHT (IN CM): 8.2

ORIFICE DIAMETER (IN CM):

13.8

DIAMETER AT BOTTOM OF

RIM OR NECK (IN CM): 13.7

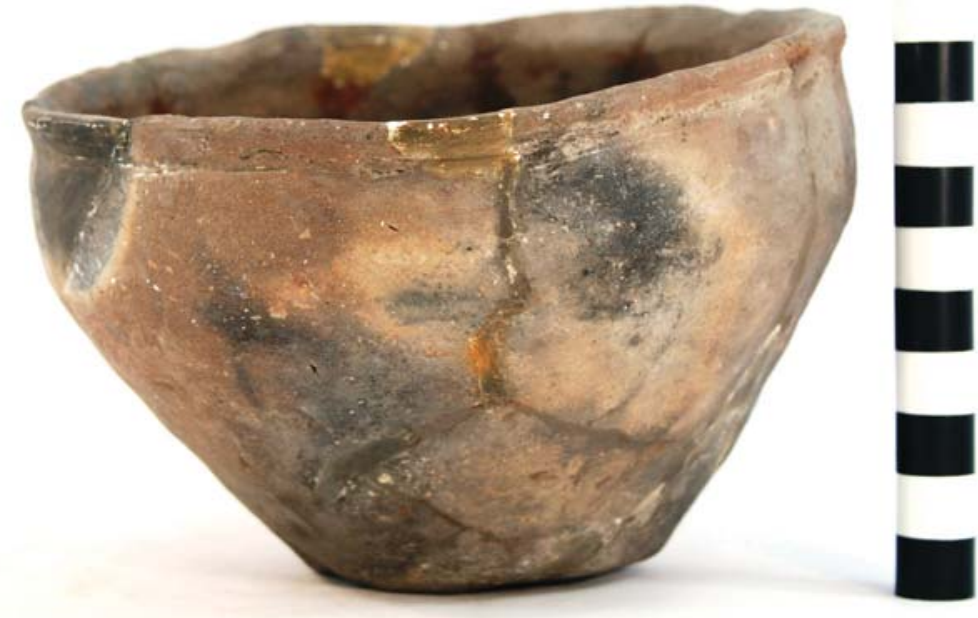

Figure 44. Plain carinated bowl from Burial X-11 at the W. A. Ford site (41TT2).

BASE DIAMETER (IN CM)

AND SHAPE OF BASE: 5.7;

circular and concave

ESTIMATED VOLUME (IN LITERS): 0.68

DECORATION (INCLUDING MOTIF AND ELEMENTS WHEN APPARENT): Plain (Figure 44)

PIGMENT USE AND LOCATION ON VESSEL: none

TYPE AND VARIETY (IF KNOWN): Unidentified plain ware 
SITE NAME OR SITE NUMBER: W. A. Ford (41TT2)

VESSEL NO.: 58, Burial X-11

VESSEL FORM: Jar

NON-PLASTICS AND PASTE: grog

RIM AND LIP FORM: Everted rim, and missing lip

CORE COLOR: $\mathrm{G}$ (fired in a reducing environment and cooled in the open air)

INTERIOR SURFACE COLOR: grayishbrown

EXTERIOR SURFACE COLOR:

yellowish-brown; fire clouds on the rim and upper body

WALL THICKNESS (IN MM): rim, 7.9 $\mathrm{mm}$; body, $8.4 \mathrm{~mm}$

INTERIOR SURFACE TREATMENT: smoothed

EXTERIOR SURFACE TREATMENT: smoothed on the body

HEIGHT (IN CM): 20.3+; body height is $17.2 \mathrm{~cm}$

ORIFICE DIAMETER (IN CM): 15.3

DIAMETER AT BOTTOM OF RIM OR NECK (IN CM): 15.9

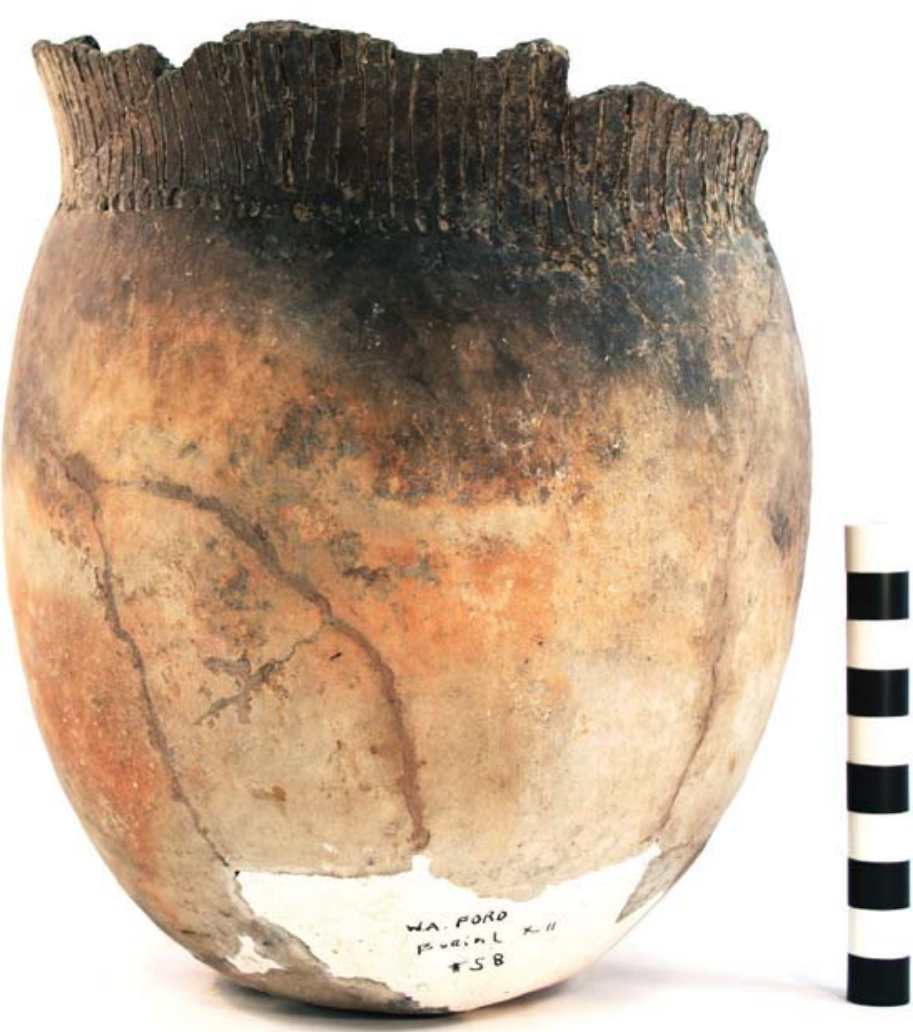

Figure 45. Incised-punctated jar from Burial X-11 at the W. A. Ford site (41TT2).

BASE DIAMETER (IN CM) AND SHAPE OF BASE: 7.0; circular and flat

ESTIMATED VOLUME (IN LITERS): $>2.8$

DECORATION (INCLUDING MOTIF AND ELEMENTS WHEN APPARENT): The rim is decorated with a continuous series of vertical incised lines above a horizontal row of tool punctations at the rim-body juncture (Figure 45).

PIGMENT USE AND LOCATION ON VESSEL: none

TYPE AND VARIETY (IF KNOWN): Unidentified utility ware 
SITE NAME OR SITE NUMBER: W. A. Ford (41TT2)

VESSEL NO.: 59, Burial X-11

VESSEL FORM: Jar with four rim peaks

NON-PLASTICS AND PASTE: shell

RIM AND LIP FORM: Everted rim and rounded lip

CORE COLOR: B (fired and cooled in a reducing environment)

INTERIOR SURFACE COLOR: very dark grayish-brown

EXTERIOR SURFACE COLOR: very dark grayish-brown

WALL THICKNESS (IN MM): rim, $5.4 \mathrm{~mm}$

INTERIOR SURFACE TREATMENT: burnished on the rim

EXTERIOR SURFACE

TREATMENT: burnished

HEIGHT (IN CM): 10.8

ORIFICE DIAMETER

(IN CM): 12.3

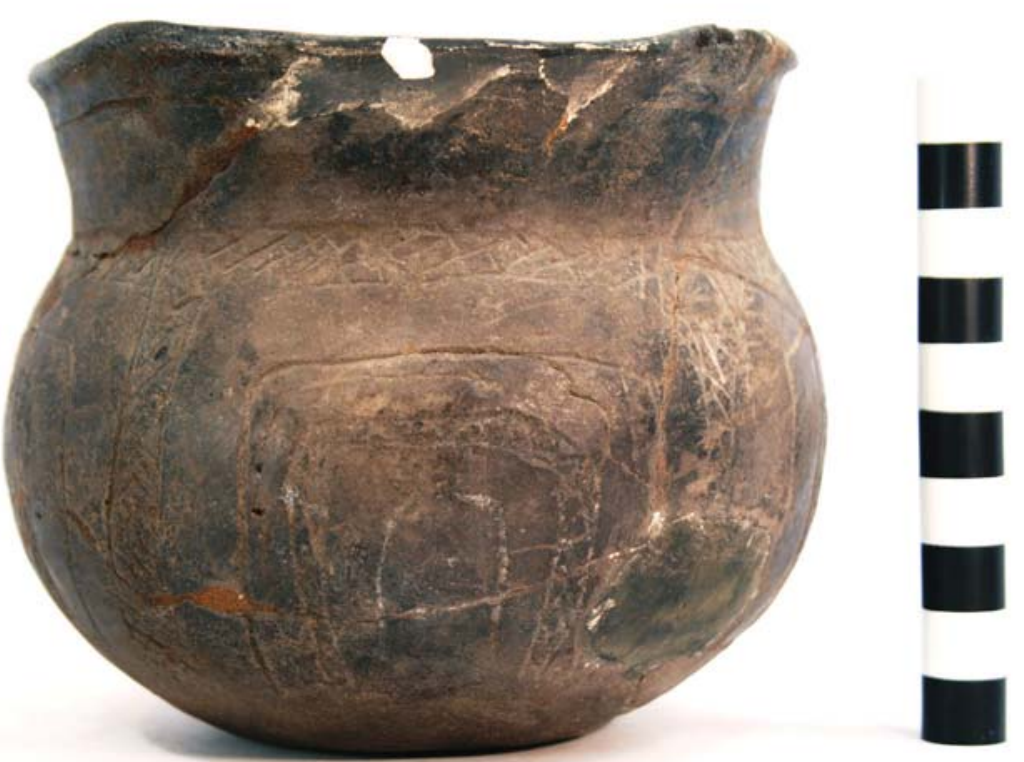

Figure 46. Engraved jar from Burial $\mathrm{X}-11$ at the W. A. Ford site (41TT2).

DIAMETER AT BOTTOM OF

RIM OR NECK (IN CM): 10.3

BASE DIAMETER (IN CM) AND SHAPE OF BASE: 5.1; circular and flat

ESTIMATED VOLUME (IN LITERS): 0.80

DECORATION (INCLUDING MOTIF AND ELEMENTS WHEN APPARENT): The rim has two horizontal engraved lines, one near the mid-rim and the other at the rim-body juncture (Figure 46). The vessel body has four panels defined by repeating sets of horizontal and vertical engraved zones filled with cross-hatched engraved lines. Within each of the four panels is a single outer engraved curvilinear line, a horizontal and vertical cross-hatched zone filled with cross-hatched engraved lines, and an inner curvilinear engraved line (Figure 46).

PIGMENT USE AND LOCATION ON VESSEL: none

TYPE AND VARIETY (IF KNOWN): Unidentified fine ware, cf. Avery Engraved 
SITE NAME OR SITE NUMBER: W. A. Ford (41TT2)

VESSEL NO.: 61, Burial X-11

VESSEL FORM: Jar with four rim peaks

NON-PLASTICS AND PASTE: grog

RIM AND LIP FORM: Everted rim and rounded lip

CORE COLOR: $\mathrm{G}$ (fired in a reducing environment and cooled in the open air)

INTERIOR SURFACE COLOR: grayishbrown; organic residue band on the body

EXTERIOR SURFACE COLOR:

yellowish-brown; fire clouds on the rim, body, and base; organic residue on the body

WALL THICKNESS (IN MM): rim, 7.5 $\mathrm{mm}$

INTERIOR SURFACE TREATMENT: smoothed

EXTERIOR SURFACE TREATMENT: smoothed on the body

HEIGHT (IN CM): 28.4

ORIFICE DIAMETER (IN CM): 24.8

DIAMETER AT BOTTOM OF RIM OR NECK (IN CM): 22.6

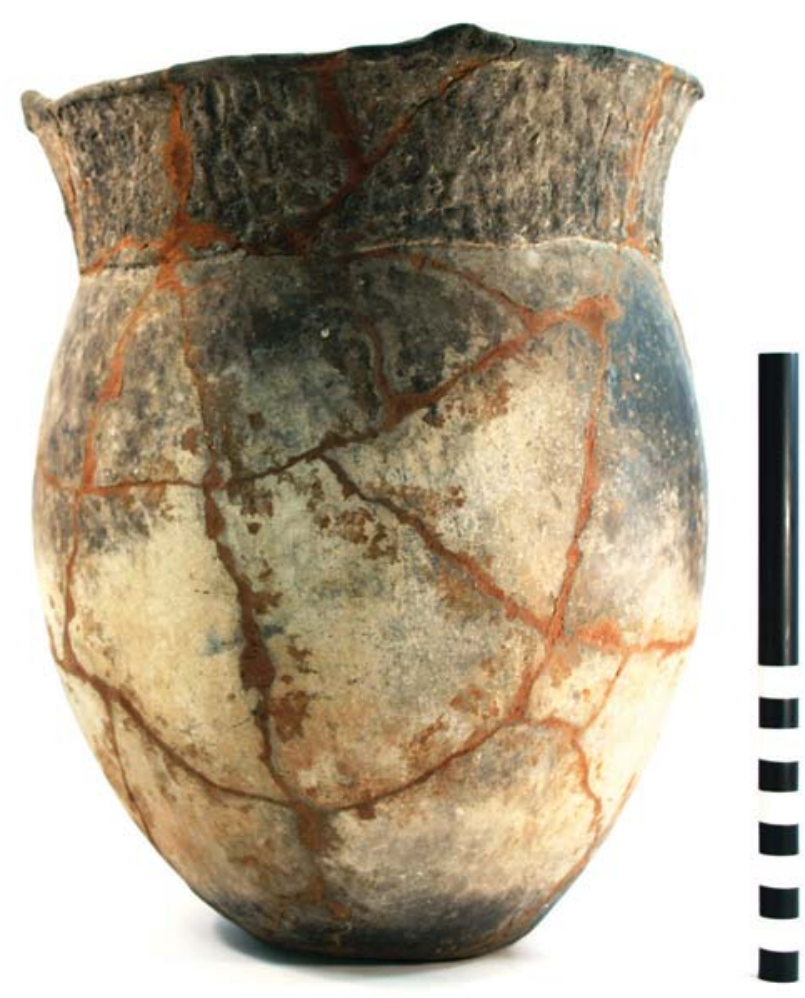

Figure 47. La Rue Neck Banded jar from Burial X-11 at the W. A. Ford site (41TT2).

BASE DIAMETER (IN CM) AND SHAPE OF BASE: 7.6; circular and flat

ESTIMATED VOLUME (IN LITERS): 9.1

DECORATION (INCLUDING MOTIF AND ELEMENTS WHEN APPARENT): The rim of the vessel has four horizontal neck banded rows (Figure 47).

PIGMENT USE AND LOCATION ON VESSEL: none

TYPE AND VARIETY (IF KNOWN): La Rue Neck Banded 
SITE NAME OR SITE NUMBER: W. A. Ford (41TT2)

VESSEL NO.: 62, Burial X-11

VESSEL FORM: Carinated bowl

NON-PLASTICS AND PASTE: grog

RIM AND LIP FORM: Direct rim and rounded, exterior folded lip

CORE COLOR: F (fired in a reducing environment and cooled in the open air)

INTERIOR SURFACE COLOR: brown

EXTERIOR SURFACE

COLOR: brown

WALL THICKNESS (IN MM):

rim, $5.7 \mathrm{~mm}$

INTERIOR SURFACE

TREATMENT: smoothed

EXTERIOR SURFACE

TREATMENT: burnished

HEIGHT (IN CM): 10.2

ORIFICE DIAMETER (IN

CM): 16.7

DIAMETER AT BOTTOM OF

RIM OR NECK (IN CM): 16.6

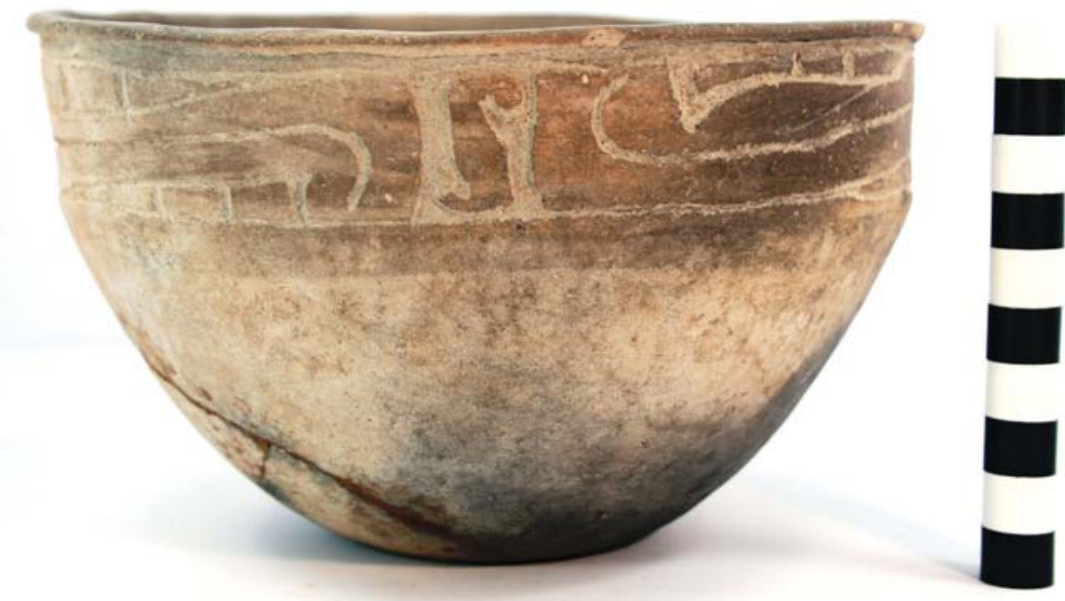

Figure 48. Ripley Engraved, var. Gandy (Vessel 62) carinated bowl from Burial X-11 at the W. A. Ford site.

BASE DIAMETER (IN CM) AND SHAPE OF BASE: 6.4; circular and rounded

ESTIMATED VOLUME (IN LITERS): 1.0

DECORATION (INCLUDING MOTIF AND ELEMENTS WHEN APPARENT): The rim panel has an engraved scroll motif repeated four times around the vessel. The scrolls are divided by four sets of negative S-shaped elements (Figure 48). The upper and lower scroll fill zones have excised brackets, triangles, and rectilinear elements.

PIGMENT USE AND LOCATION ON VESSEL: none

TYPE AND VARIETY (IF KNOWN): Ripley Engraved, var. Gandy 


\section{Other Reported Funerary Objects or Possible Funerary Objects}

Other artifact classes were also placed with the deceased in the W. A. Ford site cemetery, according to Goldschmidt (1934). Burial X-1 had a green clay pigment inside Vessel No. 1, along with a single arrow point, while there was a small chipped stone knive in Burial $X-2$. Burial $X-4$ also had a single arrow point, and a chipped stone tool was in Burial X-7.

Several mussel shells were among the funerary offerings in Burial $\mathrm{X}-8$, including two shells under one of the vessels, a third in a ceramic vessel, and a fourth just southwest of another ceramic vessels; there were also pieces of quartz in the southwestern corner of the burial. Burial X-8 also had 12 arrow points of the Maud and Talco types (see Goldschmidt 1935b:Plate 11:148:3-4) (Figure 49). A small ground stone celt was also in Burial X-8; it had been placed inside one of the ceramic vessels (Vessel No. 21). Three Maud or Talco arrow points were among the offerings in Burial X-9, along with a number of animal bones, including a beaver incisor tooth placed by Vessel No. 48 .

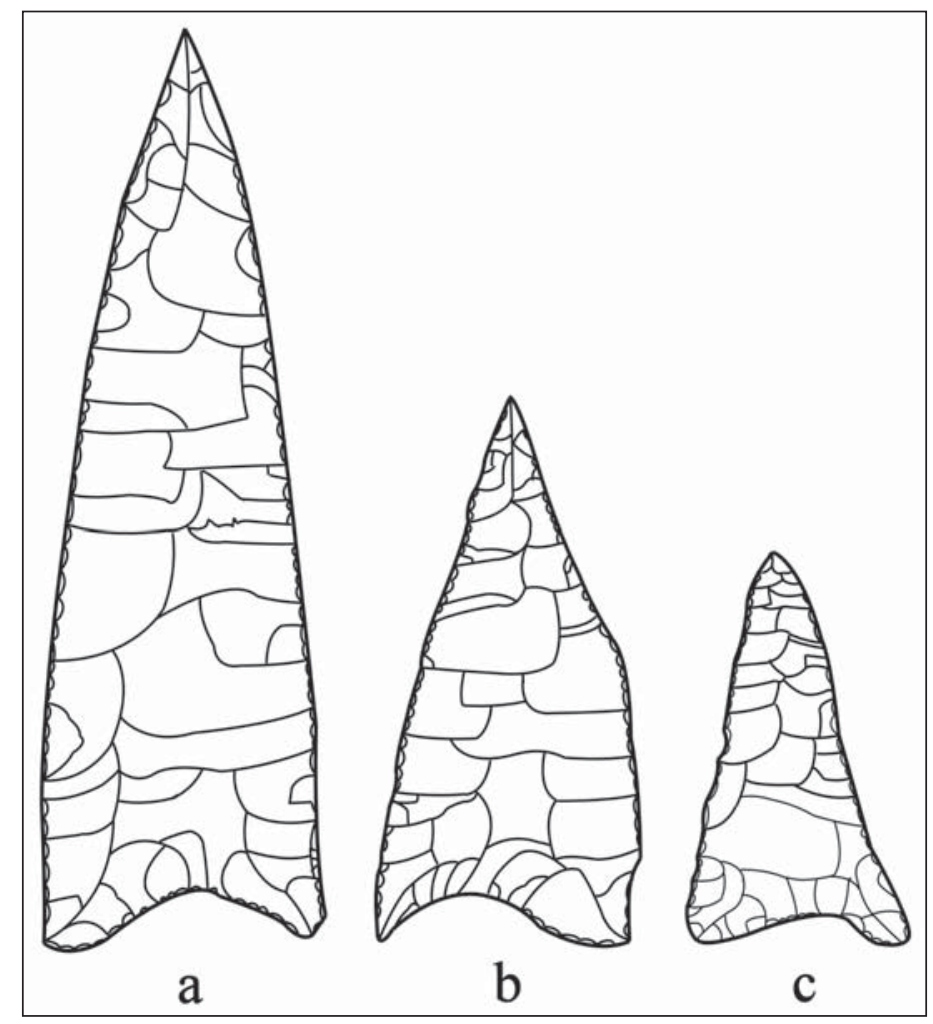

Figure 49. Maud and Talco arrow points in Burial X-8 (after Goldschmidt 1934:23).

A total of 16 Maud or Talco arrow points were among the funerary offerings in Burial X-11, placed in several clusters (quivers?) in the burial pit (Goldschmidt 1934:33, 36; see also Goldschmidt 1935b:Plate 11). There was also a concentration of red clay along the south side of the burial pit. Finally, in the northeastern part of the general excavations, a bear canine tooth was recovered in the work. It had not been modified, but it is dubious it is just a general find, and likely also came from a burial context. 


\section{SUMMARY AND CONCLUSIONS}

The W. A. Ford is a Woodland and ancestral Caddo settlement and cemetery on an alluvial rise in the Sulphur River valley in the Blackland Prairie in East Texas. University of Texas archaeologists conducted extensive excavations at the site in August and September 1934, under the direction of Walter R. Goldschmidt, and identified 11 burial features (Burials $\mathrm{X}-1$ to $\mathrm{X}-11$ ) on the rise. Habitation deposits consisted of a scattering of ceramic vessel sherds, projectile points (both dart points and arrow points), burned clay pieces, charcoal, and animal bones, but no habitation features were located in the block and trench excavations.

The burial features at the W. A. Ford site can be divided into three groups based on the character of the burial features themselves (i.e., their orientation, position, and number of interments in each grave) as well as their associated funerary offerings. Except for Burial X-4, where no human remains were recovered, the burials were clearly placed in an extended supine position in graves, with the heads of the deceased generally facing to the west or west-southwest. One burial feature (Burial X-8) had two individuals, but the others are the graves of single individuals, both adolescents and adults.

The first burial group, and the earliest group of burials at the W. A. Ford site, includes Burials $\mathrm{X}-1$ to $\mathrm{X}-4$. Other burials likely associated with this group of interments are Burial $\mathrm{X}-5$ and $\mathrm{X}-10$; these latter two burials did not have any funerary offerings, and Burial $\mathrm{X}-10$ was intersected by a later burial from the third and latest burial group (Burial $X-9$ ). The first four burials in this group had eight ceramic vessels as funerary offerings, a mean of only 2.0 vessels per burial. These are grog- $(50$ percent $)$, bone- (25.0 percent), and grog-bone- (25.0 percent) tempered vessels, including two jars, five bowls, and one carinated bowl. Approximately 62 percent of the vessels are plain, one has appliqued nodes, another is a Canton Incised vessel with incised-punctated decorative elements, and the last vessel in the group has simply executed incised-punctated decorative elements. Although there are no radiocarbon dates from these vessels, it is

suspected that they are from early Caddo burials that likely predate ca. A.D. 1000; the absence of engraved vessels in this group is notable.

The second group of burials includes Burial X-6 and X-7; Burial X-6 was placed in a grave pit where the head of the deceased faced to the east-northeast. There are three vessels from Burials X-6 and X-7; a mean of 1.5 vessels per burial. These vessels are grog- 67 percent) and grog-bone- (33 percent) tempered everted rim Mockingbird Punctated jars (67 percent) and bowls (33 percent). Mockingbird Punctated is a grog-tempered utility ware jar form found in Titus phase ceramic assemblages primarily in the Big Cypress Creek basin (see Perttula et al. 1998). The rims are decorated with several rows of horizontal tool punctations, and the vessel body is commonly plain. Some rim punctated jars of the Mockingbird Punctated type in Titus phase assemblages have vertically brushed bodies, or appliqued nodes along the rim-body juncture, or vertical appliqued fillets on the vessel body. The vessels in this second group of burials are decorated either with rows of punctates or have engraved elements featuring an SZ element. Although it has been noted by Gadus (2013:237) that the SZ element on ceramic vessels was employed as early as the Early Caddo period (ca. A.D. 1000-1200), its occurrence together in a grave with a Mockingbird Punctated everted rim jar suggests these vessels and burials postdate ca. A.D. 1400; they may well be contemporaneous with the third group of burials and vessels.

The last, and third, group of vessels includes Burials $X-8, X-9$, and $X-11$ in the eastern part of the cemetery; Burial $X-9$ cut through an earlier burial (Burial $X-10$ ). These burials have a mean of 8.3 vessels as funerary offerings, as well as a number of triangular Maud or Talco arrow points. The vessels in this burial group are tempered with grog ( 72 percent), grog-bone ( 8 percent), and shell (20 percent); the shell-tempered vessels were likely not manufactured locally (see Selden et al. 2014), but were apparently manufactured by McCurtain phase Caddo potters living on the middle reaches of the Red River to the north of the W. A. Ford site, and traded or exchanged with a local Sulphur River Caddo population. The vessels include jars (28 percent), bowls ( 4 percent), carinated bowls ( 52 percent), bottles ( 8 percent), and compound bowls ( 8 percent). The types represented in the shell-tempered vessels from these burials are Emory Punctated- 
Incised, Simms Engraved, var. Darco, Simms Plain (a red-slipped deep bowl), and Avery Engraved (n=2); these are common McCurtain phase types (Perttula 2013:194 and Figures 10-11). Early historic Caddo sites with Simms Engraved, var. Darco vessels include the Hatchel (41BW3) and Sam Kaufman (41RR16, Skinner et al. 1969:Figure 21c) sites on the Red River.

The grog and grog-bone-tempered vessels $(\mathrm{n}=20)$ in this last burial grouping feature Titus phase types (Perttula 2013:Figures 12 and 13), including Ripley Engraved ( $\mathrm{n}=8$ vessels) carinated bowls and compound bowls, including var. Carpenter and var. Galt, Wilder Engraved $(\mathrm{n}=2)$ bottles, and La Rue Neck Banded $(n=3)$ jars. There are also four plain vessels, two incised-punctated and appliqued utility ware vessels, and a vessel with an unidentified engraved motif.

The combination of grog, grog-bone, and shell-tempered vessels with a variety of decorative elements and motifs in Burials $\mathrm{X}-8, \mathrm{X}-9$, and $\mathrm{X}-11$ suggests they are from burials that date to the Titus phase of the Late Caddo period, from ca. A.D. 1430-1680. Because of the forms of Simms Engraved and Simms Plain vessels in Burials $X-8$ and $X-9$, it is possible to suggest that these burials and vessels date to the late $17^{\text {th }}$ century A.D., but prior to any sustained contact with European groups. Burial X-11 may be the earliest burial in this third grouping, and dates sometime before the late $17^{\text {th }}$ century in the Titus phase.

\section{ACKNOWLEDGMENTS}

I appreciate the assistance provided by Jonathan Jarvis and Marybeth Tomka in accessing the ceramic vessels from the W. A. Ford site. Bo Nelson took the photographs of the vessels used in this article, and Lance Trask and Sandy Hannom prepared the various figures.

\section{REFERENCES CITED}

Gadus, E. F.

2013 Twisted Serpents and Fierce Birds: Structural Variation in Caddo Engraved Ceramic Bottle Motifs. Bulletin of the Texas Archeological Society 84:213-245.

Goldschmidt, W. R.

1934 Field Notes, W. A. Ford Site, Titus County, Texas, August 21, 1934 to September 5, 1934. MS on file, Texas Archeological Research Laboratory, The University of Texas at Austin.

1935a Some Archeological Sites in Titus County and Their Relation to East Texas Prehistory. Master's thesis, Department of Anthropology, The University of Texas at Austin.

1935b A Report on the Archeology of Titus County in East Texas. Bulletin of the Texas Archeological and Paleontological Society 7:89-99.

Jones, B. C.

1968 The Kinsloe Focus: A Study of Seven Historic Caddoan Sites in Northeast Texas. Master's thesis, Department of Anthropology, University of Oklahoma, Norman.

Perttula, T. K.

2013 Caddo Ceramics in East Texas. Bulletin of the Texas Archeological Society 84:181-212.

Perttula, T. K., B. Nelson, R. L. Cast, and B. Gonzalez

2010 The Clements Site (41CS25): A Late 17th to Early 18th-Century Nasoni Caddo Settlement and Cemetery. Anthropological Papers No. 92. American Museum of Natural History, New York.

Perttula, T. K., M. Tate, H. Neff, J. W. Cogswell, M. D. Glascock, E. Skokan, S. Mulholland, R. Rogers, and B. Nelson

1998 Analysis of the Titus Phase Mortuary Assemblage at the Mockingbird Site Kahbakayammaahin" (41TT550). Document No. 970849. Espey, Huston \& Associates, Inc., Austin. 
Selden, R. Z., Jr., T. K. Perttula, and D. L. Carlson

2014 INAA and the Provenance of Shell-Tempered Sherds in the Ancestral Caddo Region. Journal of Archaeological Science 47:113-120.

Skinner, S. A., R. K. Harris, and K. M. Anderson (editors)

1969 Archaeological Investigations at the Sam Kaufman Site, Red River County, Texas. Contributions in Anthropology No. 5. Department of Anthropology, Southern Methodist University, Dallas.

Suhm, D. A., and E. B. Jelks (editors)

1962 Handbook of Texas Archeology: Type Descriptions. Special Publication No. 1, Texas Archeological Society, and Bulletin No. 4, Texas Memorial Museum, Austin. 